\title{
Seasonal dynamics of microbial sulfate reduction in temperate intertidal surface sediments: controls by temperature and organic matter
}

\author{
Abdul M. Al-Raei • Katja Bosselmann • \\ Michael E. Böttcher • Britta Hespenheide • \\ Franz Tauber \\ Received: 20 September 2008 / Accepted: 24 February 2009 /Published online: 4 April 2009 \\ (C) The Author(s) 2009. This article is published with open access at Springerlink.com
}

\begin{abstract}
The role of microbial sulfate reduction on organic matter oxidation was studied quantitatively in temperate intertidal surface sediments of the German Wadden Sea (southern North Sea) on a seasonal base in the years 1998-2007. The sampling sites represent the range of sediments found in the back-barrier tidal area of Spiekeroog Island: sands, mixed and muddy flats. The correspondingly different contents in organic matter, metals, and porosities lead to significant differences in the activity of sulfatereducing bacteria with volumetric sulfate reduction rates
\end{abstract}

Responsibe Editor: Meinhard Simon

Abdul M. Al-Raei, Katja Bosselmann, and Michael E. Böttcher contributed equally to the study.

A. M. Al-Raei · K. Bosselmann · M. E. Böttcher $(\bowtie) \cdot$

B. Hespenheide

Department of Biogeochemistry,

Max Planck Institute for Marine Microbiology,

Celsiusstr.1,

28359 Bremen, Germany

e-mail: michael.boettcher@io-warnemuende.de

F. Tauber

Marine Geology, Leibniz Institute for Baltic Sea Research,

Seestr.15,

18119 Warnemünde, Germany

Present address:

K. Bosselmann

Forschungs- und Technologiezentrum Westküste (FTZ),

Hafentörn 1,

25761 Büsum, Germany

Present address:

M. E. Böttcher

Marine Geochemistry, Leibniz Institute for Baltic Sea Research,

Seestr.15,

18119 Warnemünde, Germany

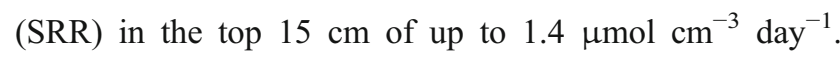
Depth-integrated areal SRR ranged between 0.9 and $106 \mathrm{mmol} \mathrm{m}^{-2}$ day $^{-1}$, with the highest values found in the mudflat sediments and lower rates measured in sands at the same time, demonstrating the impact of both temperature and organic matter load. According to a modeling approach for a $154-\mathrm{km}^{2}$ large tidal area, about 39,122 , and 285 tons of sulfate are reduced per day, during winter, spring/ autumn, and summer, respectively. Hence, the importance of areal benthic organic matter mineralization by microbial sulfate reduction increases during spring/autumn and summer by factors of about 2 and 7, respectively, when compared to winter time. The combined results correspond to an estimated benthic organic carbon mineralization rate via sulfate reduction of $78 \mathrm{~g} \mathrm{C} \mathrm{m}^{-2}$ year $^{-1}$.

Keywords Microbial sulfate reduction - Organic matter.

Surface sediments $\cdot$ Temperature $\cdot$ Pore waters .

Intertidal flats · Sulfide oxidation · Wadden Sea .

Southern North Sea

\section{Introduction}

"The oldest high-culture of the North, the glorious Atlantis,... is buried in the Wadden Sea below a metersthick mud-layer for thousands of years!" (translated from Ingwersen 2005). The tidal zone of the North Sea has not only stimulated the imagination of modern novelists but is nowadays also still the site for impressive new scientific findings.

In near shore waters, high nutrient concentrations lead to increased phytoplankton growth which generates up to $30 \%$ of the total ocean primary production (e.g., Walsh 1991; 
Wollast 1991). Most of the organic matter in further remineralized instead of buried in the sea bed. In estuarine and shallow sea ecosystems, sulfate reduction has shown to be most active and account for about $20 \%$ to $40 \%$ of the global sulfate reduction (Skyring 1987). With increasing distance from the coastal region, mineralization processes mainly take places under oxic and suboxic conditions. Therefore, much lower SRR were found in continental slope and deep sea sediments (Jørgensen 1982; Boetius et al. 2000). Tidal areas, in particular, represent highly productive marine coastal ecosystems that are under additional influence of riverine inputs by loads of detritus and dissolved and particulate organic matter (Vosjan 1987; Volkman et al. 2000; Rullkötter 2006; Freese et al. 2008). These intertidal sediments are exposed to a number of physical, biological, and chemical processes, resulting in complex and dynamic interactions between the biogeochemical element cycles. The back-barrier tidal areas of the German Wadden Sea form an important transition zone between the terrestrial and marine environment. The sedimentary system is exposed to semidiurnal changes between inundation and air exposure, which forces the sedimentary microbial and biogeochemical activity to reflect a highly dynamic environment superimposed by seasonal and meteorological changes (Reineck 1982; Dittmann 1999; Stanev et al. 2003). The remineralization of organic matter is coupled to reductive processes using oxygen, nitrate, manganese/iron oxy(hydroxi)des, and sulfate as final electron acceptors (e.g., Froelich et al. 1979). Dissimilatory microbial sulfate reduction may contribute by more than $50 \%$ to the organic matter mineralization in continental shelf sediments (Jørgensen 1982; Skyring 1987; Canfield et al. 1993). It is the most important anaerobic process leading to a reflux of carbon dioxide into the water column (e.g., Thamdrup 2000; Jørgensen 2006). The biogeochemical processes at the sediment-water interface of intertidal systems are under influence of highly dynamic boundary conditions, as, for instance, light intensity, temperature, water pressure, hydrodynamics (e.g., current intensities, irrigation, advection, sediment resuspension), oxygen penetration, organic matter load, and salinity (e.g., Boudreau and Jørgensen 2001).

Gross rates of microbial sulfate reduction (SRR) in intertidal and salt marsh sediments have been reported to vary considerably with values rates between 0.2 and $240 \mathrm{mmol} \mathrm{m}^{-2}$ day $^{-1}$ (Schröder 1983; Vosjan 1987; Skyring 1987; Trudinger 1992; Kostka et al. 2002). The highest seasonal variations are expected in the top sediments (Böttcher et al. 2000; de Beer et al. 2005). Earlier investigations have shown that the intensity of microbial sulfate reduction in marine surface sediments is mainly controlled by temperature and the availability of degradable organic matter (Vosjan 1974; Westrich and Berner 1988;
Hansen et al. 1993; Rusch et al. 1998; Pomeroy and Wiebe 2001), and controls the fractions of sedimentary sulfur, iron, and partly manganese compounds that are finally buried in the sediment. This leads to a coupling of the biogeochemical carbon, sulfur, and metal cycles (Berner 1989). However, only about $10 \%$ of the sulfide produced by microbial sulfate reduction in continental shelf sediments is permanently buried in the sediment, indicating an efficient chemical or microbial reoxidation of sulfide to finally sulfate (Jørgensen 1982; Westrich and Berner 1988; Moeslund et al. 1994; Thamdrup et al. 1994). Organic matter (OM) load, on the other hand, is often associated with the sedimentary mud fractions (grain size fractions below $63 \mu \mathrm{m}$ ) indicating an at least indirect control of OM contents by sedimentation conditions (e.g., Mayer et al. 1985; Delafontaine et al. 1996; Böttcher et al. 2000). In addition, bacterial cell numbers as a measure for overall potential microbial activity show a positive correlation with the sedimentary mud fraction (DeFlaun and Mayer 1983; Böttcher et al. 2000). The quantitative relevance of the different factors on the control of microbial sulfate reduction and their spatial and temporal dynamics in intertidal sediments may also depend on site-specific factors and are still not fully understood (Hubas et al. 2006).

It was the particular goal of the present study to investigate the role of microbial sulfate reduction on organic carbon mineralization in different intertidal surface sediments of a back-barrier tidal area in the southern North Sea. The studied sites are representative for a range of sediment types under influence of different hydrodynamic regimes, leading to differences in grain size distribution, permeability, and organic matter and metal contents. Results were obtained on a seasonal basis and indicate the important influences of both temperature and organic matter load and allow the development of a quantitative budget of the role of microbial sulfate reduction for mineralization of reduced organic carbon in the whole tidal system.

\section{Materials and methods}

\subsection{Study areas}

The study sites are located in the back-barrier tidal area of Spiekeroog Island in the southern North Sea (Fig. 1). The different sampling sites cover the range of sediments with different sedimentological and geochemical properties (e.g., grain size, organic matter and metal content, permeability, and porosity) and biological activities characteristic for the study area. Detailed site descriptions are given by Hespenheide (1999), Böttcher et al. (2000), Llobet-Brossa 


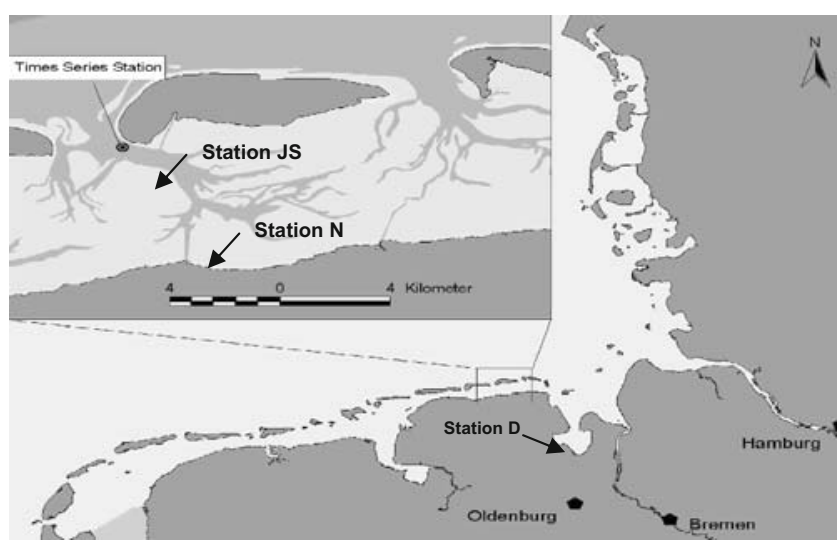

Fig. 1 Study area in the back-barrier tidal area of Spiekeroog Island and the Jade Bay

et al. (2002), Batels (2003), Peters (2004), Theune (2005), Stevens et al. (2005), and Billerbeck et al. (2006, 2007). Geographical positions, sampling dates, and site characterizations are compiled in Table 1. According to the grain size-based sediment classification (Irion 1994), the intertidal surface sediments of the Janssand flat (JS-I and JS-III) and at Neuharlingersiel (N-I and N-II) represent sandy and mixed sediments, respectively (Table 1). Whereas JS-III is positioned on the top of the Janssand plate, site JS-I is located close to the mean low-water level. Due to higher hydrodynamic tidal variations, the sediments display some vertical variations in lithology and also on a spatial and temporal scale leading to an interfingering of sandy and more muddy layers. In addition, this is the place of temporally preferred burial of macroalgae during summer time. As an analog for muddy sediments in the study area (due to biological (mussel banks) or physical mud enrichment (Flemming and Ziegler 1995; Chang et al. 2007), a mudflat in the close-by Jade Bay (site Dangast (D); Fig. 1) has been chosen for the comparative investigation. An overall introduction into different ecological aspects of the tidal study area can be found in Dittmann (1999, and references therein) and Stanev et al. (2003).

Table 1 Compilation of field campaigns and different site-specific characteristics

\begin{tabular}{|c|c|c|c|c|c|}
\hline & \multicolumn{5}{|l|}{ Site } \\
\hline & JS-III & JS-I & N-I & N-II & $\mathrm{D}$ \\
\hline Latitude & $53^{\circ} 44^{\prime} 07^{\prime \prime} \mathrm{N}$ & $53^{\circ} 44^{\prime} 08^{\prime \prime} \mathrm{N}$ & $53^{\circ} 42^{\prime} 90^{\prime \prime} \mathrm{N}$ & $53^{\circ} 42^{\prime} 90^{\prime \prime} \mathrm{N}$ & $53^{\circ} 26^{\prime} 43^{\prime \prime} \mathrm{N}$ \\
\hline Longitude & $7^{\circ} 41^{\prime} 57^{\prime \prime} \mathrm{E}$ & $7^{\circ} 41^{\prime} 58^{\prime \prime} \mathrm{E}$ & $7^{\circ} 42^{\prime} 32^{\prime \prime} \mathrm{E}$ & $7^{\circ} 42^{\prime} 33^{\prime \prime} \mathrm{E}$ & $8^{\circ} 06^{\prime} 30^{\prime \prime} \mathrm{E}$ \\
\hline Sampling & $7 / 2001,12 / 2001,4 / 2002$ & $12 / 2001,4 / 2002$ & $7 / 2001,8 / 2001$ & $11 / 2002$ & $4 / 1998,5 / 1998$ \\
\hline \multirow[t]{4}{*}{ campaigns } & $6 / 2002,10 / 2002,7 / 2003$ & $6 / 2002,10 / 2002,7 / 2003$ & $4 / 2002,6 / 2002$ & $4 / 2004$ & 6/1998, 7/1998 \\
\hline & $3 / 2004,11 / 2004,4 / 2005$ & $3 / 2004,11 / 2004,4 / 2005$ & $10 / 2002,8 / 2003$ & & 8/1998, 1/1999 \\
\hline & $7 / 2005,11 / 2005,3 / 2006$ & $7 / 2005,11 / 2005,3 / 2006$ & $11 / 2004$ & & $6 / 1999,1 / 2000$ \\
\hline & $7 / 2006,10 / 2006,3 / 2007$ & $7 / 2006,10 / 2006,3 / 2007$ & $11 / 2005$ & & $12 / 2003,1 / 2005$ \\
\hline$T$ range $\left[{ }^{\circ} \mathrm{C}\right]$ & $4-31$ & $4-31$ & $7-32$ & $5-16$ & $1-24$ \\
\hline \multicolumn{6}{|l|}{ Grain sizes $[\%]$} \\
\hline$<2 \mu \mathrm{m}$ & 0.6 & 1.1 & 6.0 & n.d. & 15.4 \\
\hline$<63 \mu \mathrm{m}$ & 1.0 & 3.1 & 21.3 & n.d. & 84.5 \\
\hline$<580 \mu \mathrm{m}$ & 98.3 & 95.7 & 100.0 & n.d. & 99.5 \\
\hline $\mathrm{H}_{2} \mathrm{O}[\mathrm{wt} . \%]$ & $18-21$ & $18-30$ & $21-33$ & $35-84$ & $36-88$ \\
\hline Permeability $\left[\mathrm{m}^{-2}\right]$ & $8.3( \pm 1.1) \times 10^{-12}$ & $1.8( \pm 1.3) \times 10^{-12}$ & $6.0( \pm 0.2) \times 10^{-14}$ & n.d. & n.d. \\
\hline TOC [dwt.\%] & $0.01-0.1$ & $0.01-0.8$ & $0.3-1.2$ & $1.2-3.8$ & $1.3-3.5$ \\
\hline OPD [cmbsf] & 4.2 & 4.0 & 2.5 & n.d. & 0.5 \\
\hline $\mathrm{Fe}^{*}[$ dwt.\%] & 0.04 & 0.07 & 0.2 & 0.8 & 1.9 \\
\hline $\mathrm{Mn} *[\mathrm{mg} / \mathrm{kg}]$ & 40 & 63 & 179 & 700 & 800 \\
\hline $\mathrm{Fe}^{2+},{ }_{\text {,aq }}[\mu \mathrm{M}]$ & 200 & 100 & 200 & 80 & 280 \\
\hline $\mathrm{Mn}^{2+},{ }_{\text {aq }}[\mu \mathrm{M}]$ & 100 & 200 & 200 & 60 & 250 \\
\hline
\end{tabular}

Sediment parameters are given for the top $10 \mathrm{cmbsf}$ that were measured at selected occasions. Extractable iron $\left(\mathrm{Fe}^{*}\right)$ and manganese $\left(\mathrm{Mn}^{*}\right)$ contents are maximum values, typically found in the top $\mathrm{cm} . \mathrm{Fe}^{2+}$, aq and $\mathrm{Mn}^{2+}$, aq are maximum values typically found between 2 and $10 \mathrm{cmbsf}$; details are given in Bosselmann et al. (in preparation) and Böttcher et al. (2000; in preparation). T range represents values observed during sampling campaigns. Sandy (JS), mixed (N-I, N-II), and muddy (D, N-II) sites refer to positions given in Fig. 1. Grain size data are given for one sampling campaign. OPD: Approximate maximum oxygen penetration depth measured in situ with lander-based microsensors in the field (JS: Werner et al. 2003; Billerbeck et al. 2006; N-I: Bird and Walpersdorf 2002, personal communication), and in situ or ex situ (D: Böttcher et al. 2000; Llobet-Brossa et al. 2002) under light conditions. Permeability: Top 15 (JS) and $4 \mathrm{~cm}$ (N-I), respectively (Billerbeck et al. 2006, 2007).

n.d. not determined 
The tides in the study area are semidiurnal. The Janssand flat is characterized by a slope of on average $1.6 \mathrm{~cm} \mathrm{~m}^{-1}$ toward the low-water line and is covered by approximately 1.5 to $2 \mathrm{~m}$ of water during high tide. Sampling occurred along a transect with the lower sand flat position near the low water line (JS-I) and an upper sand flat site (JS-III, approximately $45 \mathrm{~m}$ upslope the sand flat) chosen as representative for the Janssand plate. The upper parts of this tidal flat become exposed to air for about 6 to $7.5 \mathrm{~h}$, the lower position falls dry for 3-4 h during low tide (Billerbeck et al. 2006). Macrofaunal abundance in the study area has been investigated by Hertweck (1995). It was observed that low macrofaunal abundance at exposed sides at the Janssand sites is a result of enhanced current velocities. High current velocities, further enhanced by the adjacent ferry way cannel, lead to a permanent reworking of the sediments at JS-I. The intertidal mixed flat sites N-I and N-II are located close to the coastal harbor of Neuharlingersiel and become exposed for about 6 to $7 \mathrm{~h}$ during low tide (Theune 2005; Billerbeck et al. 2007). Site $\mathrm{N}-\mathrm{I}$ is positioned about $25 \mathrm{~m}$ away from a protection dam of clay retention pits that protect the intertidal coast lines. Site N-II, on the other hand, was directly positioned close (less than 2 meters away) to the outlet of a clay retention pit. Compared to site N-I, site N-II is characterized by less dynamic sedimentation conditions, with a slight morphological depression, leading to permanent water coverage of at least several centimeters even during low tide. It, therefore, had a higher total organic carbon (TOC) content due to enhanced fine-grained sediment fractions (Batel 2003; Peters 2004). The mudflat site D, positioned in the southern Jade Bay close to the small village Dangast (Fig.1), is influenced by the fluvial input of the river Weser (Pasche et al. 2008). The tidal cycles lead to an inundation time of about $7 \mathrm{~h}$ and an exposure time of about $5 \mathrm{~h}$. The top 10 to $15 \mathrm{~cm}$ of the sediment is dominated by the mud fraction (Böttcher et al. 2000, in preparation).

Field studies were carried out during numerous field campaigns between years 1998 and 2007 (Table 1). Seawater temperatures in the back-barrier area varied during the different seasons from $1^{\circ} \mathrm{C}$ in winter and up to $31^{\circ} \mathrm{C}$ during summer time.

\subsection{Sampling and analytical procedures}

Several parallel sediment cores (polyvinyl chloride tubes; 2.6 to $10 \mathrm{~cm}$ width; $20-40 \mathrm{~cm}$ length) were sampled in an area of about $1 \mathrm{~m}^{2}$ during low tide. Field sampling platform for the Janssand studies was a flat bottom boot (tjalk; Fig. 2). Both, sediments and interstitial waters were typically analyzed down to about $15 \mathrm{~cm}$ depth for a number of parameters: SRR, total reduced inorganic sulfur (TRIS), acid volatile sulfur (AVS), chromium-reducible

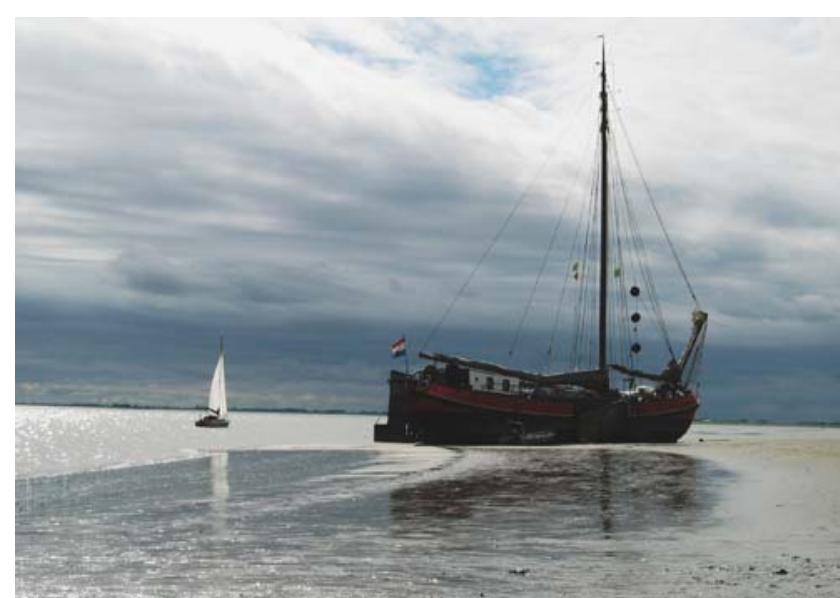

Fig. 2 The sampling position close to the main tidal channel near site JS-I at rising tide together with the sampling field platform for the Janssand plate: a Dutch tjalk (July 2005; photograph: M.E. Böttcher)

sulfur (CRS), TOC, total inorganic carbon (TIC), $\mathrm{SO}_{4}{ }^{2-}$, $\mathrm{H}_{2} \mathrm{~S}, \mathrm{Fe}^{2+}, \mathrm{Mn}^{2+}$, extractable $\mathrm{Fe}(\mathrm{III})$ and $\mathrm{Mn}$ (III,IV) oxides, salinity, and water contents. The vertical grain size distributions were measured at selected occasions. Vertical profiles of pore water temperatures were measured in situ with digital manual sensors (Omnitherm Pt100; MASCOM 1CHA). Additionally, nutrients and metabolic products (e.g., $\mathrm{PO}_{4}, \mathrm{NH}_{4}{ }^{+}$, silica, DIC) were analyzed as described by Billerbeck et al. (2006). Results for the latter one and the redox-sensitive metals $\mathrm{Mn}$ and $\mathrm{Fe}$ will be presented in detail in related publications (Bosselmann et al., in preparation; Al-Raei et al., in preparation). Table 1 compiles maximum values for observed extractable iron ( $\left.\mathrm{Fe}^{*}\right)$, manganese $\left(\mathrm{Mn}^{*}\right)$, and dissolved $\mathrm{Fe}^{2+}$,aq and $\mathrm{Mn}^{2+}$,aq.

After sectioning the core in a glove box under inert gas (sites JS and N-I between 2001 and 2004), pore waters were separated from the sediments by centrifugation (centrifuge tubes similar to the device published by Saager et al. 1990) through membrane filters $(0.45 \mu \mathrm{m})$. Pore waters from years 2005 to 2007 were taken at depths of 1 , $3,5,8,10,13$, and $15 \mathrm{~cm}$ below surface (cmbsf) with about 20-cm-long pore water zippers made of PEEK tubing connected to plastic syringes and immediately filtered through $0.45 \mu \mathrm{m}$ disposable membrane filters into prepared different sampling vials. An aliquot of ZnAc-preserved pore waters (except for JS sites in years 2002-2004) was used for photometric sulfide measurements according to Cline (1969). After centrifugation, the determination of dissolved sulfate was carried out from the same aliquots using a Dionex LC30 DX 500 or WATERS ion chromatograph. Chloride was measured via ion chromatography, to account for effects of possible salinity changes. The concentration of dissolved $\mathrm{Fe}^{2+}$ was measured using Ferrozine reagent with 1\% hydroxylamine hydrochloride (Stookey 1970). Another aliquot of pore water was acidified (p.a. grade 
$\mathrm{HNO}_{3}$ ) and the concentration of dissolved $\mathrm{Fe}^{2+}$ and $\mathrm{Mn}^{2+}$ were measured after appropriate dilution by inductively coupled plasma (ICP) optical emission spectrometry (Perkin Elmer Optima 3000 XL (at ICBM) or Thermo, iCAP 6300 Duo (at IOW)) with Sc as an internal standard or by ICP mass spectroscopy (Thermo Finnigan MAT ELEMENT at ICBM). Salinity of the pore water samples was measured with a hand refractometer (Atago, SI Mill-E). Sediments and pore waters from site Dangast were processed and analyzed as described in Böttcher et al. (2000; in preparation), Hespenheide (1999), and LlobetBrossa et al. (2002).

Parallel sediment cores were analyzed in $1 \mathrm{~cm}$ intervals down to about $25 \mathrm{~cm}$ for porosity by measuring wet density and water content (drying at $105^{\circ} \mathrm{C}$ for $24 \mathrm{~h}$ ). For the determination of the grain size distribution, freeze-dried sediment samples were pretreated with $\mathrm{H}_{2} \mathrm{O}_{2}(30 \%)$ and washed with distilled water, subsequently dried and analyzed by laser deflection (Fritsch Analysette 22 at ICBM Wilhelmshaven or a Laser Sizer Cilas $1180 \mathrm{~L}$ at IOW). Total carbon (TC) was measured from freeze-dried samples using a CNS element analyzer (Fison Instruments, NA 1500, Series 2) and TIC on a CM $5012 \mathrm{CO}_{2}$ coulometer with a CM 5130 acidification module (UIC). TOC contents were calculated from the difference of TC and TIC. The two-step distillation procedure was used to extract the acid volatile sulfur (AVS $=\mathrm{FeS}+\mathrm{H}_{2} \mathrm{~S}+\mathrm{HS}^{-}$) and chromium reducible sulfur $\left(\mathrm{CRS}=\mathrm{FeS}_{2}+\right.$ minor $\left.\mathrm{S}^{0}\right)$. Selected cores were analyzed using the one-step distillation method to obtain the sum of the AVS and CRS fractions (total reducible inorganic sulfur; Fossing and Jørgensen 1989; Kallmeyer et al. 2004). Sulfide measurements were carried out by the methylene blue method (Cline 1969), using a Shimadzu UV-160A or an Analytik Jena AG Specord 40 spectrophotometer. Extractable $\mathrm{Fe}^{*}$ was determined from freeze-dried sediment using buffered dithionitecitrate acetic acid solution (Canfield 1989) or $0.5 \mathrm{M} \mathrm{HCl}$ (Thamdrup et al. 1994; Kostka and Luther 1994); extractable $\mathrm{Mn}^{*}$ was measured from extracts with $0.5 \mathrm{M} \mathrm{HCl}$ (Thamdrup et al. 1994). Microbial SRR were measured by the whole-core incubation technique (e.g., Fossing and Jørgensen 1989; Kallmeyer et al. 2004). For this purpose, several parallel sediment cores ( $2.6 \mathrm{~cm}$ wide) were sampled at each site. Sediment cores were transported to the laboratory and kept under in situ temperature and dark conditions for further processing. Parallel cores were preequilibrated for about $12 \mathrm{~h}$ in thermoconstant cold rooms or incubators at one to three different temperatures bracketing or averaging the daily temperature range observed in the field. After pre-equilibration, carrier-free ${ }^{35} \mathrm{SO}_{4}{ }^{2-}$-radiotracer solution was injected in 1 to $2 \mathrm{~cm}$ intervals down to about $15 \mathrm{cmbsf}$. After several hours of incubation in the dark, the sediment cores were sliced into $1 \mathrm{~cm}$ sections and immediately mixed with $10 \mathrm{ml}$ of a $20 \%$ solution of zinc acetate to interrupt the microbial process and to fix the labile sulfides as $\mathrm{ZnS}$. The activity of ${ }^{35} \mathrm{~S}$ was determined using a Packard Liquid scintillation counter (2500IR). Temperature dependence of the overall sulfate reduction process was calculated according to the Arrhenius equation (e.g., Vosjan 1974; Westrich and Berner 1988; Thamdrup et al. 1998; Kristensen et al. 2000; Benner et al. 2002). The empirical results were used to interpolate the measured depth-integrated SRR for the top $15 \mathrm{~cm}$ to the mean daily temperature. SRR data for site N-II and 2001 data for N-I and JS-III are taken from Batel (2003), Peters (2004), and Theune (2005), respectively. For the SRR results from JS and N-I stations in years 2002-2004, daily temperature fluctuations were considered too (Bosselmann and Böttcher 2008).

The image map www.icbm.de/watt/intern/sedimente1996_ohnetext.gif" (Fig. 10; loaded in September 2008) was used as sedimentological background for calculating total areal rates of sulfate reduction. The scale of the map was calculated from the extension of the scale bar in "sedimente1996.gif". The calculation of the areas of the different sediment types given in the map was conducted using the image processing software package "Adobe Photoshop".

\section{Results and discussion}

\subsection{General sediment and pore water properties}

The Janssand stations JS-I and JS-III are characterized as well-sorted fine-grained sands (Billerbeck et al. 2006). The water contents ranged from $16 \%$ to $21 \%$ at the upper sand flat station III. Sediments at the lower station I contained finer-grained layers in various depths and showed correspondingly higher water contents of up to more than $30 \%$. The mixed sediments of station $\mathrm{N}$ consisted of various grain size classes but enhanced mud factions. The top sediments at the Dangast site (D) were dominated by the mud fraction (Böttcher et al. 2000; in preparation; Table 1). The high capacity of clay minerals to adsorb organic matter is typically reflected in the research area by a positive correlation with the TOC contents (Delafontaine et al. 1996; Böttcher et al. 2000). Overall, the pore water salinities varied from about 22 (sites D and $\mathrm{N}$ ) to maximum surface values of 35 in summer (sites JS). Salinities in the German Bight, however, typically vary only between 29 and 34 (Böttcher et al. 2007a, b; Dellwig et al. 2007). Differences to this range are due to dilution with freshwater, supplied to the Wadden Sea by tidal inlets, rivers, and ground water, or concentration due to evaporation of tidal rest waters during summer time. 
The four sites are characterized by different organic matter contents (Table 1). Seasonal TOC variations were typically found in the top $5 \mathrm{~cm}$ of the sediment with decreases further downcore. The top $5 \mathrm{~cm}$ at the mudflat station D, for instance, contained about 3 dwt.\% TOC which decreased to about $1 \mathrm{dwt} \%$ at $20 \mathrm{cmbsf}$. At station $\mathrm{N}$, the highest surface TOC contents reached about $1.3 \mathrm{dwt}$. $\%$ and decreased to a content of 0.4 to $0.7 \mathrm{dwt} . \%$. In contrast, the sandy JS sites I+III contained much less organic matter. TOC values at JS-I, for instance, ranged from 0.1 to about $0.8 \mathrm{dwt} . \%$ (Table 1), with enhanced TOC contents only found in certain distinct layers associated with enhanced mud contents. Station JS-III showed relatively small variations between 0.06 and $0.1 \mathrm{dwt} . \%$ TOC. The higher TOC contents at JS-I compared to JS-III are the result of the different hydrodynamic conditions. Different current dynamics at the low waterline compared to the top site during low tide support accumulation of mud and particulate organic matter, including macroalgae, into the sandy sediment. Sediment surfaces at site JS-I were reduced as indicated by black coloration due to $\mathrm{FeS}$ formation (e.g., Böttcher 2003; Böttcher et al. 1998). As shown by stable carbon isotope measurements on the TOC fraction, the bulk organic matter is a mixture between easily degradable marine $\mathrm{OM}$ and less reactive terrestrial or peatderived OM (Böttcher et al. 1998, 2000; Volkman et al. 2000; Peters 2004; Theune 2005; Freese et al. 2008). Only the reactive fraction is degradable by microorganisms at higher rates (e.g., Schubert et al. 2000; Pomeroy and Wiebe 2001). Böttcher et al. (2000), for instance, estimated varying relative marine fractions up to about $70 \%$ in the top sediments at site D. Similar relative marine fractions were obtained for sites N (Peters 2004; Theune 2005) and JS-III (Böttcher, unpublished results). Therefore, the TOC contents are mostly higher than the reactive organic carbon fraction. In addition, biogenic methane may contribute to carbon-sulfur cycling at site JS-1 (see next section).

\subsection{Net microbial sulfate reduction}

Pore water sulfate concentrations in the intertidal area behave conservatively, as long as no microbial (sulfate reduction, sulfide oxidation) or chemical (sulfide oxidation) processes act as source or sink for sulfate and a corresponding net change in the ratio between sulfate and salinity (e.g., Vosjan 1974, 1987). Microbial dissimilative sulfate reduction is associated with sulfide production according to the overall reaction (e.g., Froelich et al. 1979),

$$
\begin{aligned}
& \left(\mathrm{CH}_{2} \mathrm{O}\right)_{106}\left(\mathrm{NH}_{3}\right)_{16}\left(\mathrm{H}_{3} \mathrm{PO}_{4}\right)+53 \mathrm{SO}_{4}{ }^{2-}+14 \mathrm{H}^{+} \\
& \rightarrow 106 \mathrm{HCO}_{3-}+16 \mathrm{NH}_{4}{ }^{+}+\mathrm{HPO}_{4}{ }^{2-}+53 \mathrm{H}_{2} \mathrm{~S}
\end{aligned}
$$

Net sulfate reduction was generally observed in the top sediments of station JS-I (Fig. 3), with some seasonal variations. In accordance with results from downward net sulfate decrease, dissolved sulfide accumulation up to more than $15 \mathrm{mM}$ was measured in JS-I cores (Figs. 3 and 4). Localized seep-type areas with reduced sediment surfaces were observed, indicating a disturbance of the typical biogeochemical zonation and advection of anoxic pore waters from below (Fig. 5). These phenomena have previously been described for intertidal sands and attributed to local burial of metabolizable organic matter (Böttcher 2003; Böttcher et al. 1998; Freitag et al. 2003) that is often associated with near-surface methane formation and corresponding advective pore water transport toward the sediment surface (Oelschläger 2002). Using stable isotope approaches, Böttcher et al. (2007a) were able to show that the oxidation of biogenic methane contributes substantially to the DIC pool at this site. This indicates that part of the sulfate reduction is associated with oxidation of methane (Ishii et al. 2004) according to the overall reaction

$$
\mathrm{CH}_{4}+\mathrm{SO}_{4}{ }^{2}-\rightarrow \mathrm{HCO}_{3^{-}}+\mathrm{HS}^{-}+\mathrm{H}_{2} \mathrm{O}
$$

Besides near-surface methanogenesis, however, methane formation and oxidation have also been shown to occur deeper in the Janssand plate (Wilms et al. 2006, 2007) and it has been suggested that pore waters modified via bacterial catalysis at depth may probably reach the eastern boundary of the Janssand plate via deep pore water circulation patterns caused by tidal driven pressure gradients (Billerbeck et al. 2006; Beck et al. 2008a, b). The accumulation of pronounced amounts of dissolved sulfide even in the top centimeters (Fig. 3) indicates that the sediments were limited with respect to reactive iron (Table 1) and that the overall sulfide production rate was higher than the sum of the rates of in situ sulfide oxidation and sulfate supply from the bottom water. It is interesting to note that close to the main tidal channel, pore waters below sediments with reduced surfaces were enriched in metabolic products and nutrients compared to sediments with oxidized surfaces only a few meters away (Fig. 4). This reflects a heterogeneity in the sediment lithology and/or the pore water draining sediment layers, probably affected by pore water mixing. A similar phenomenon of seep-structure-like pore water profiles was observed by Oelschläger (2002) in sediments with localized near-surface organic matter burial (so called "black spots"). Minor sulfide accumulation was also observed at JS-III mainly during summer time as a result of iron limitation in the sandy sediments (Table 1; Morse 1999). In the pore waters, the net sulfate deficit was not completely balanced by the accumulated sulfide (e.g., Fig. 3), due to iron sulfide formation and possible sulfide oxidation to sulfur intermediates. 
Fig. 3 Seasonal changes of downcore profiles of dissolved sulfate and sulfide in pore waters in the sediments at five different sites. Note: Sediments at the JS-I site investigated in years 2005-2007 always displayed a reduced sediment surface. The N-II data are from Batel (2003) and Peters (2004) and the N-I (2001) data from Theune (2005). Sulfide concentrations at JS sites between March 2002 and July 2003 have only been measured via microsensors in the top $5 \mathrm{~cm}$ (Werner et al., 2003; Jansen et al. 2009). Sulfide concentrations at site D were below $30 \mu \mathrm{M}$ in the top $10 \mathrm{~cm}$ (e.g., Böttcher et al., 2000; Llobet Brossa et al. 2002). $J S$ Janssand plate, $N$ mixed flat close to Neuharlingersiel, $D$ mudflat at Dangast

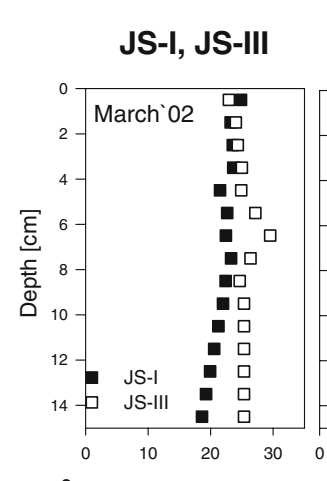

N-I

$\mathrm{N}-$ II

D

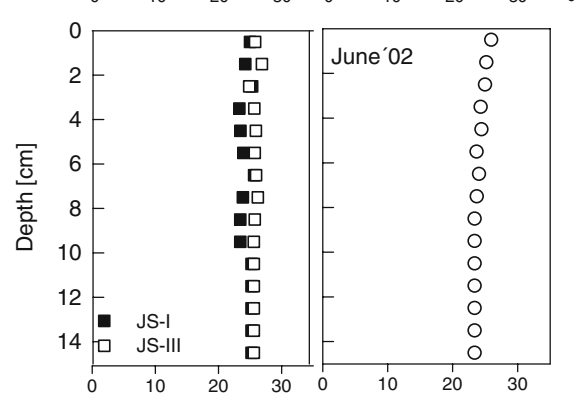

$\mathrm{SO}_{4}{ }^{2-}[\mathrm{mM}]$

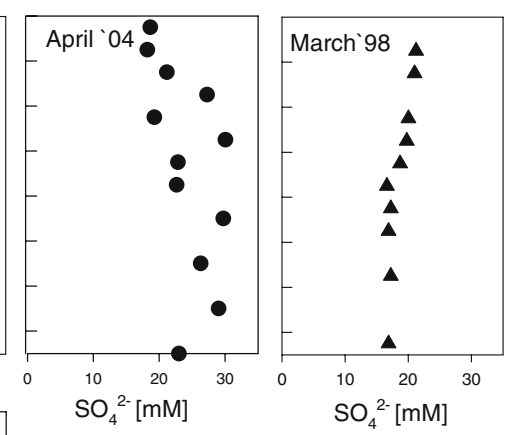

D

D
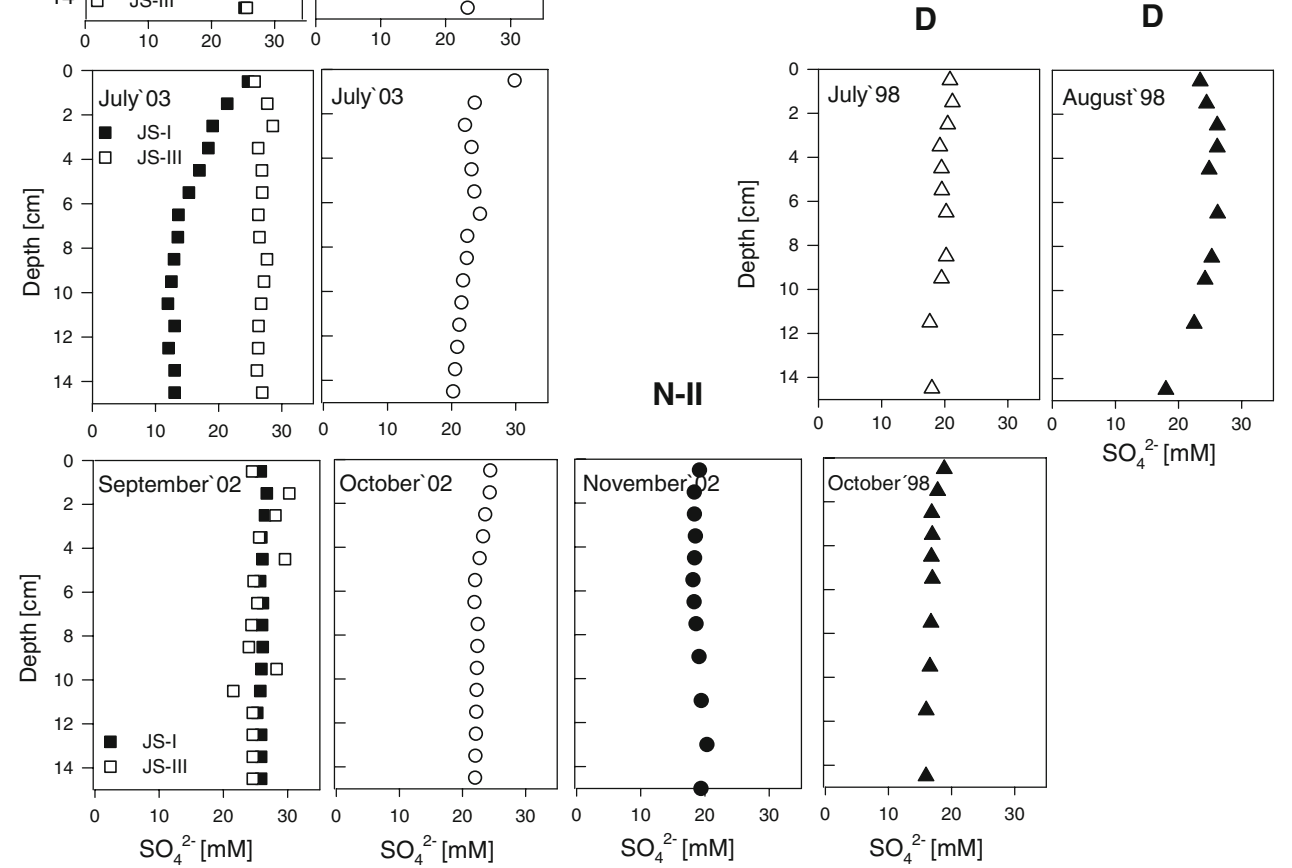

In contrast to the results from the JS-I site and summer situations at site JS-III, pore waters at the other stations indicate very minor or no substantial net sulfate reduction in the top 10 to $15 \mathrm{~cm}$ of the sediments (Fig. 3; Böttcher et al. 2000; Llobet-Brossa et al. 2002). Bacterial aerobic and metal oxide-based mineralization as well as chemical recycling processes increase in importance at these sites due to the availability of enhanced amounts of metal oxides (Table 1; Böttcher et al. 2000, 2004). This indicates that the overall process according to Eq. 1 is superimposed by, for instance, iron sulfide formation and/or sulfide oxidation to sulfur intermediates that may limit the accumulation of dissolved sulfide (e.g., Pyzik and Sommer 1981; Moeslund et al. 1994; Thamdrup et al. 1994; Dos Santos and Stumm 1992;
Böttcher et al. 2000). In addition, tidal current-driven advective pore water flow in the top of the permeable sandy sediment leads to a continuous supply of sulfate from the overlying water and bioturbating activity may enhance the pore water exchange between bottom and pore waters in sandy, mixed and muddy sediments (Boudreau and Jørgensen 2001; de Beer et al. 2005; Werner et al. 2003, 2006). Therefore, intense reoxidation processes of $\mathrm{Fe}$ - and/or hydrogen sulfides and resupply of sulfate from the overlying seawater had the effect that no net sulfate reduction was reflected in the vertical distribution of sulfate in the pore water profiles. At station $\mathrm{N}$, the depth distribution of dissolved sulfate followed a decreasing trend during all sampling campaigns in the time series. Also, the downcore profiles of sulfate in the top 10- 
Fig. 3 (continued)

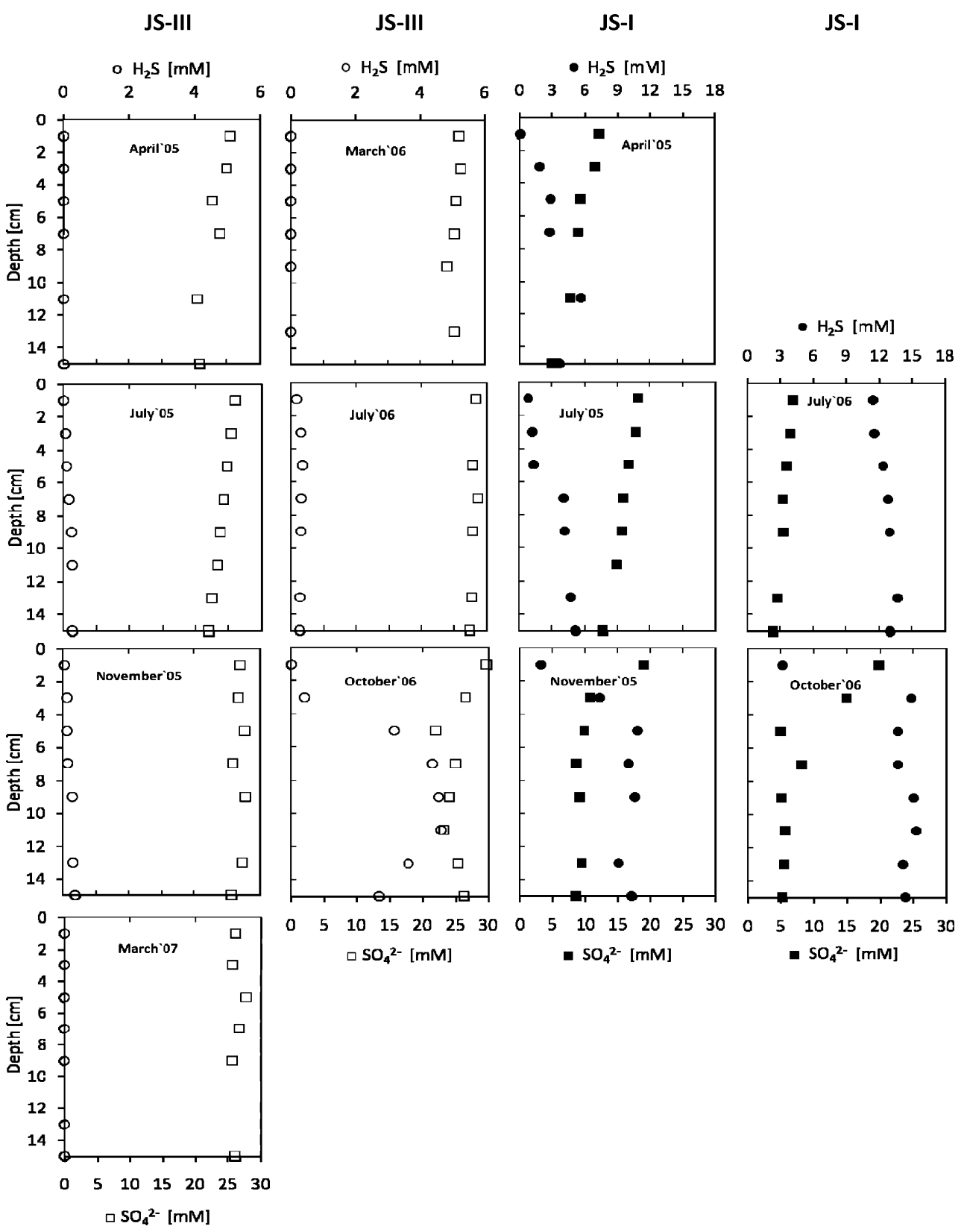

$15 \mathrm{~cm}$ at station D indicate negligible net sulfate reduction and are mainly controlled by salinity changes, as confirmed by accumulation of pore water sulfide only at higher depth (Böttcher et al. 2000; Llobet-Brossa et al. 2002).

\subsection{Gross microbial sulfate reduction}

\subsubsection{Site-specific differences: the influence of organic matter contents}

Gross microbial sulfate reduction was observed using radiotracer measurements at all sites with the highest volumetric rates in the top $15 \mathrm{~cm}$ decreasing further downcore (Fig. 6). This corresponds to highest numbers of sulfate reducing bacteria found within the top $10 \mathrm{~cm}$ at sites D, N, and JS (Böttcher et al. 2000; Llobet-Brossa et al. 2002; Ishii et al. 2004, unpublished data; Wilms et al. 2007). Lower SRR and corresponding cell numbers with depth may have been caused by the shift of the reactive to the more refractory organic matter at depth (Henrichs and Reeburgh 1987; Böttcher et al. 1998, 2000; Vosjan 1974; Westrich and Berner 1988). This trend can be explained by the preferential degradation of more easily decomposable fresh marine organic matter in the top sediments. The highest SRR were observed in the muddy sediments of site $\mathrm{D}$, closely followed by the activity in the mixed flats (sites NII and N-I). SRR observed at the sandy sites JS-I and JS-III were the lowest and the areal rates at the same time similar in 
Fig. 4 Pore water profiles at sites JS-I and III samples on October 16, 2006. In contrast to the reduced surface at site JS-I (red dots), JS-I* (red circles; sampled in a distance of a few meters away from JS-I) had an oxidized sediment surface. The surface at JS-III (green dots) was oxidized. Methane was measured from the head space of $\mathrm{NaOH}$-fixed pore waters via gas chromatography as described in Jørgensen et al. (2001). Pore water DIC, ammonium, phosphate, and silicate were analyzed as described in Billerbeck et al. (2006)

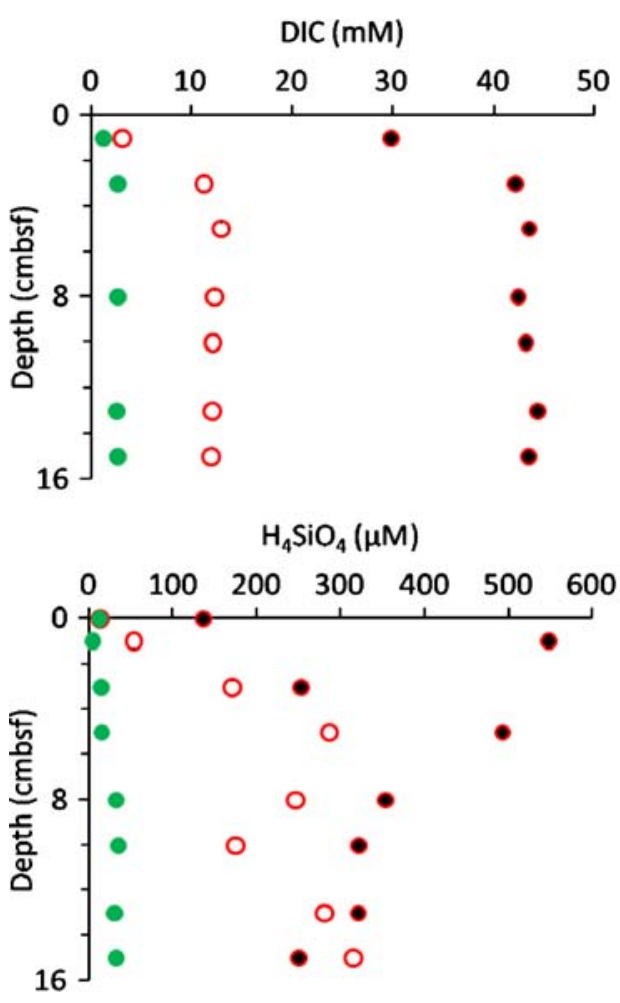

Sulfide (mM)

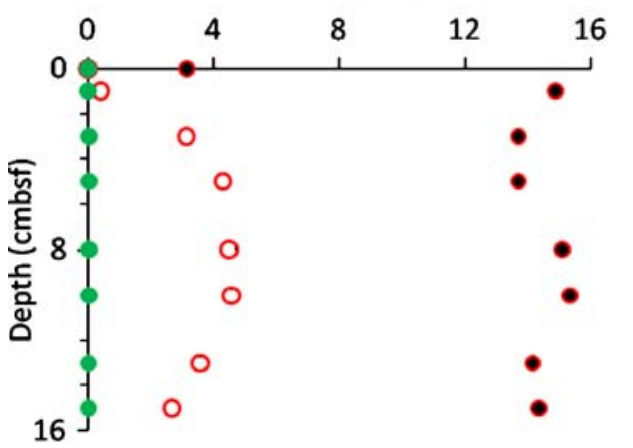

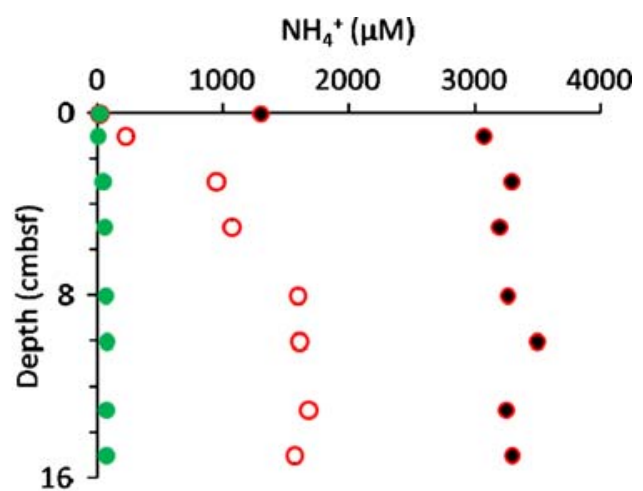

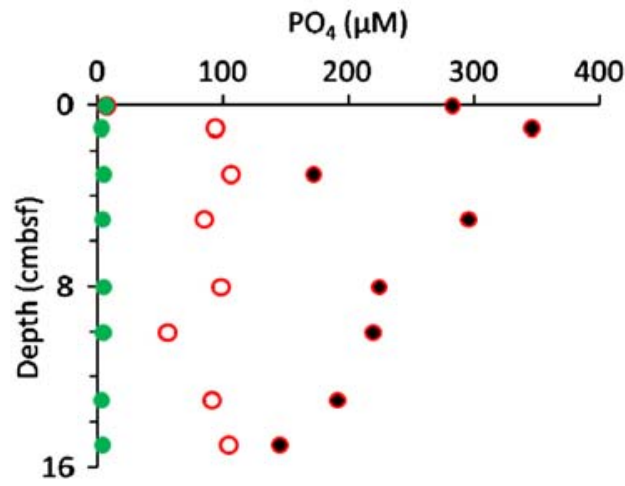

$\log \mathrm{CH}_{4}(\mathrm{mM})$

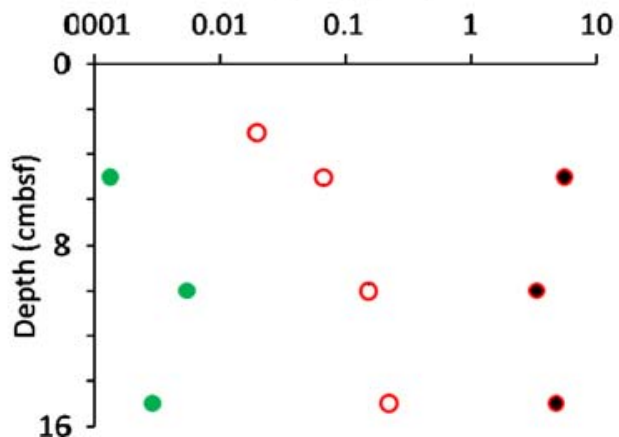

magnitude (Fig. 6). Volumetric SRR at, for instance, sites $\mathrm{N}$ and $\mathrm{D}$ ranged up to maximum values of 1,650 and $1,400 \mathrm{nmol} \mathrm{cm}^{-3}$ day $^{-1}$ during summer, respectively (Fig. 6). Depth-integrated areal sulfate reduction rates (top $15 \mathrm{~cm}$ ) ranged between 0.9 and $105 \mathrm{mmol} \mathrm{m}^{-2}$ day $^{-1}$, with the highest rates found in the mudflat sediments and much lower rates measured in sands at the same season (Fig. 7). These results clearly indicate the overall importance of the organic matter load on the gross activity of sulfate-reducing bacteria in the different intertidal sediments. The SRR at the JS sites (Fig. $7 ; 0.5$ to $14.3 \mathrm{mmol} \mathrm{m}^{-2}$ day $^{-1}$ ) are comparable to intertidal surface sands of the southeastern North Sea (Fig. 10; Böttcher et al. 2004; de Beer et al. 2005; Kristensen et al. 2000; Werner et al. 2006; Bosselmann and Böttcher, unpublished results; Al-Raei and Böttcher, unpublished results).

Microbial sulfate reduction in the organic poor sandy locations is consequently stronger influenced by the input of reactive organic matter from the water column which shows seasonal variations due to pelagic and benthic productivity changes. Activity in the sands is additionally influenced by the advective circulation of particulate and dissolved organic matter, electron acceptors, and $\mathrm{O}_{2}$ through the permeable sediments, which leads to an effective aerobic and anaerobic degradation (Shum and Sundby 1996; de Beer et al. 2005; Werner et al. 2003, 2006). Intensified currents and wave movements induced by tidal flushing lead to a further enhancement of advective transport processes in sand flats. Advective flushing of sandy layers has been shown to distribute POC (e.g., algae) and DOC into the top sediment (e.g. Hüttel et al. 1996; Hüttel and Rusch 2000). This is a filtration mechanism for organic carbon supplied into intertidal sands leading to the stimulation of bioreactor-type carbon transformations (D'Andrea et al. 2002; Hüttel et al. 1996; de Beer et al. 2005) that may partly compensate for the effect of higher 

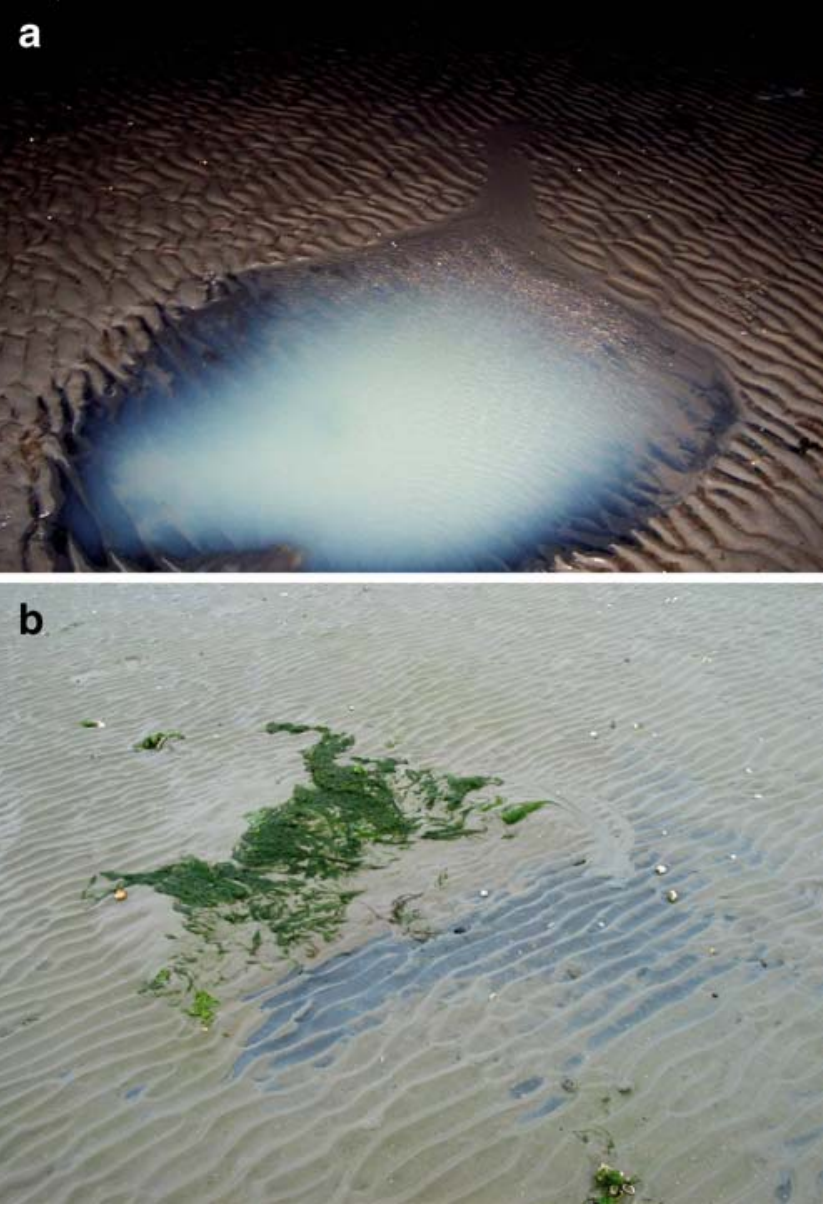

Fig. 5 Seep-type spots at low tide with reduced sediment surfaces close to site JS-I in July 2005 (photographs: M.E. Böttcher). a Pool with reduced surface and hydrogen sulfide that is oxidized in the water to colloidal elemental sulfur. b Partly buried macro algae with associated formation of reduced sediments surface

TOC contents and elevated microbial density in finegrained sediments (Musat et al. 2006). Compared to subtidal settings, the biogeochemical transformation and element exchange processes in intertidal sediments change periodically during exposure and inundation. These highly dynamic conditions enhance physical surface sediment mixing which further stimulates microbial sulfate reduction. It also enhances the transport of reduced solutes to the surface where they can be reoxidized (Hüttel et al. 1996; de Beer et al. 2005) and additionally cause a rapid resupply of oxidants and particles to the deeper sediment (Hines and Jones 1985; Berner and Westrich 1985). Transport processes, however, are also an important factor in muddy tidal sediments. In salt marsh sediments, for instance, King (1983, 1988) and Kostka et al. (2002) observed that bioturbation leads to a rapid iron turnover and stimulates sulfate reduction by decreasing sulfide concentrations through reoxidation and thereby increasing sulfate levels. Howarth and Giblin (1983) showed that, as a further factor, reoxidation processes by iron and manganese oxides keep the concentration of dissolved sulfide low, which is thermodynamically favorable for sulfate reduction but also the disproportionation of sulfur intermediates (Thamdrup et al. 1993).

\subsubsection{Seasonal variations: the effect of temperature}

In addition to OM-controlled site-specific differences, distinct seasonal variations of areal SRR were observed at all stations (Fig. 7) that can only partly be explained by changes in reactive organic matter availability (e.g. at the sandy stations due to algal blooms or enhanced benthic productivity), but is clearly reflecting pronounced changes in surface sediment temperature. The temperature-induced changes in SRR were most pronounced at the mud and mixed flat stations and much less pronounced at the sandy stations; this is probably indicative for a higher reactivity of the standing TOC stocks at the sites rich in organic matter when compared to the intertidal sands. Besides the seasonal variations, also sediment incubations at different temperatures clearly indicate the importance of sediment temperatures in the site-specific control of SRR. In general, an increase in SRR with raising temperature was observed (Figs. 8 and 9). Empirically, the experimental results can be evaluated by the application of the Arrhenius equation (e.g., Kristensen et al. 2000; Benner et al. 2002). Activation energies $\left(E_{\mathrm{a}}\right)$ derived from data fitting based on the field data have also been used to deduce qualitatively the overall reactivity of sedimentary organic matter (Westrich and Berner 1988; Kristensen et al. 2000). The evaluation of temperature dependent incubations yields activation energies, $E_{\mathrm{a}}$, between 32 and $102 \mathrm{KJ} \mathrm{mol}^{-1}$ (site D), and of $65 \mathrm{KJ} \mathrm{mol}^{-1}$ for N-II. A short-time sediment incubation of a summer N-I sediment (July 2001; Fig. 9b) at $16^{\circ} \mathrm{C}$, $25^{\circ} \mathrm{C}$, and $35^{\circ} \mathrm{C}$, for example, gave an activation energy of $46 \mathrm{KJ} \mathrm{mol}^{-1}$. Another experiment, where a site $\mathrm{D}$ winter surface sediment (January 2000; in situ temperature during field sampling- ca. $4^{\circ} \mathrm{C}$ ) was incubated at three different temperatures for several days (Fig. $9 \mathrm{a} ; 4^{\circ} \mathrm{C}, 13^{\circ} \mathrm{C}$, and $25^{\circ} \mathrm{C}$; Llobet-Brossa et al. 2000) yielded an $E_{\mathrm{a}}$ value of $32 \mathrm{KJ} \mathrm{mol}^{-1}$. An integrated site-specific evaluation of seasonal data taken during the different sampling campaigns at stations N-I, N-II, and D (Table 1) yields average values between 64 and $117 \mathrm{KJ} \mathrm{mol}^{-1}$ (correlation coefficients $r^{2}$ between 0.68 and 0.84). Higher deviations of the common evaluation of the seasonal data from an "ideal" Arrhenius fit (as indicated by lower correlation coefficients of a regression analysis) are found for the sand flat stations that may arise from slight temporal or spatial changes in the depositional environment (e.g., organic matter content and/ or quality). This effect may be more important at sandy sites compared to those sediments with a higher standing stock of organic substrate. At site JS-I, the concentration pf 


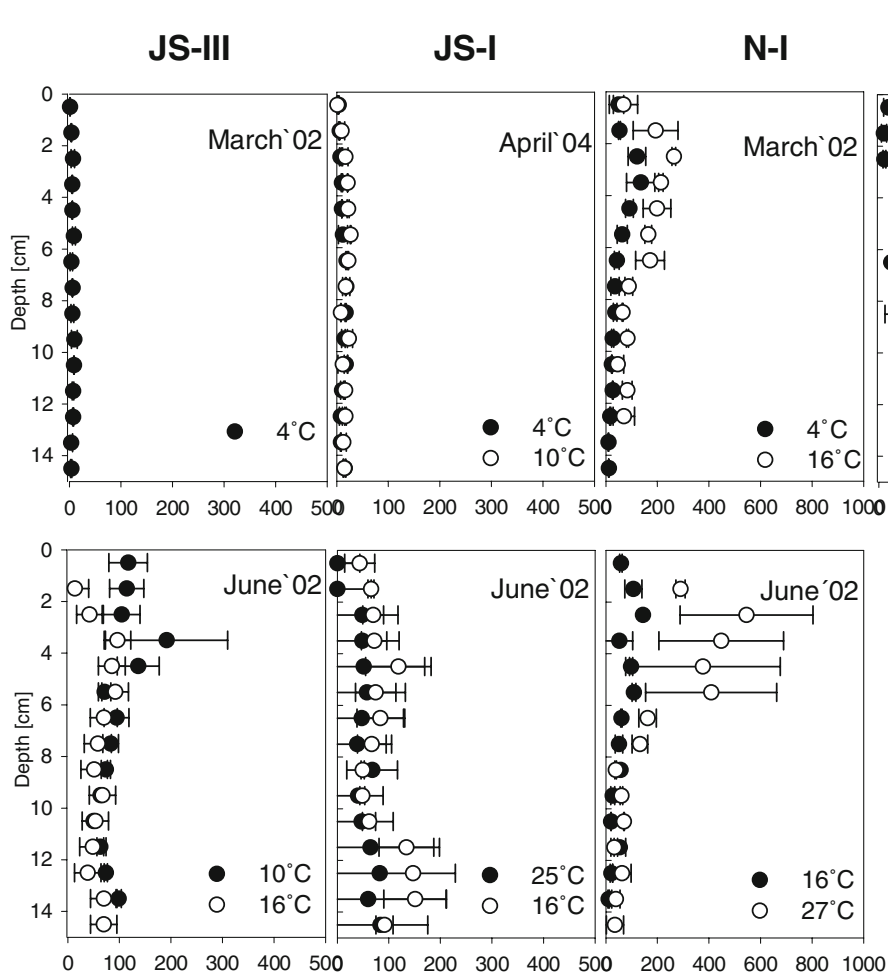

N-II D

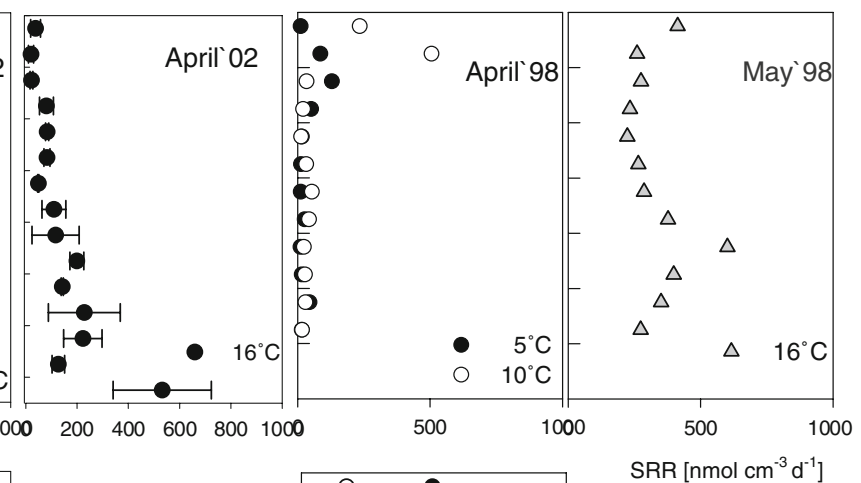

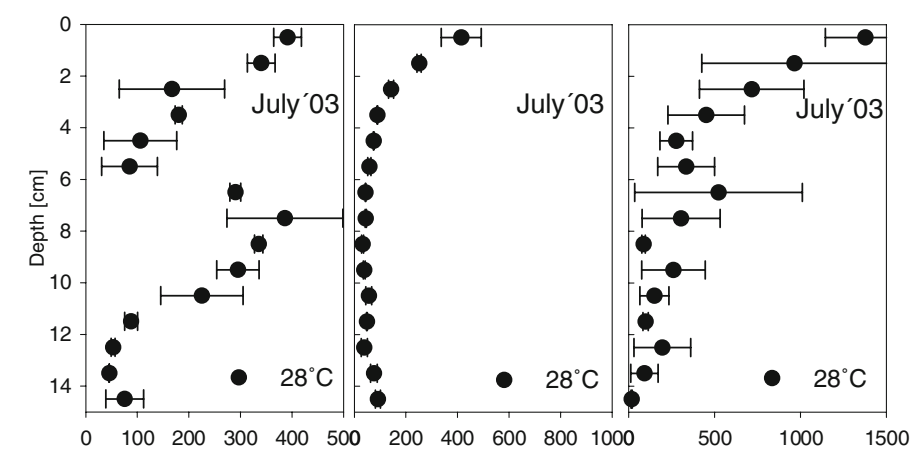
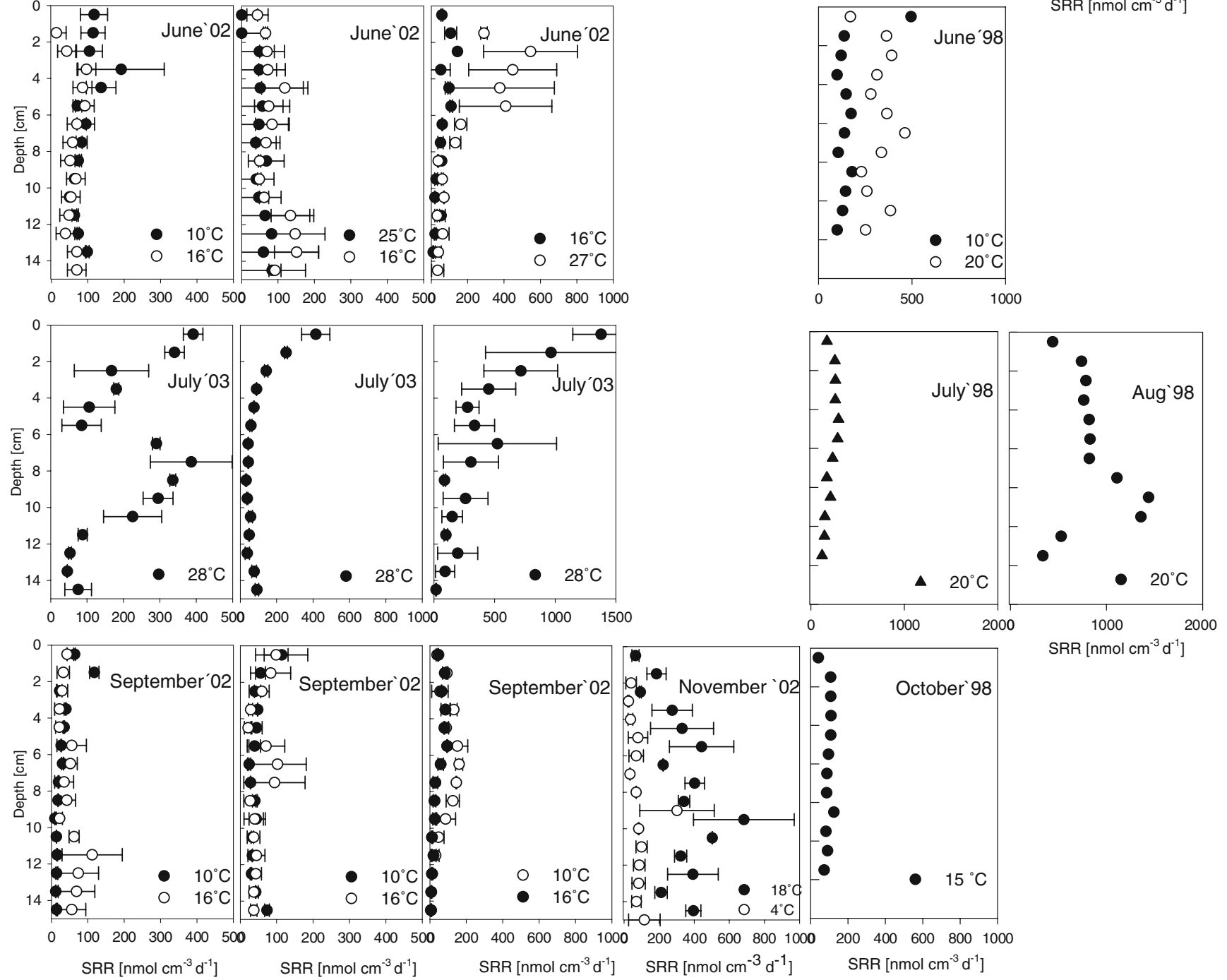

Fig. 6 Downcore profiles of volumetric sulfate reduction rates in surface sediments of mud, mixed and sand flats. Note: SRR for JS-I (marsh 2006 and 2007) were calculated based on sulfate concen- trations from November 2005. The N-II data are from Batel (2003) and Peters (2004) and the N-I (2001) data from Theune (2005). For abbreviations, see Fig. 3 pore water methane may additionally influence sulfate reduction via anaerobic methane oxidation (M. Krüger, personal communication, 2008). The results are within the brackets of apparent $E_{\mathrm{a}}$ values in previous studies from temperate coastal marine sediments that have been reported to vary between 21 and $134 \mathrm{KJ} \mathrm{mol}^{-1}$ (Jørgensen 1977; Skyring 1987; Westrich and Berner 1988; Moeslund et al. 1994; Kristensen et al. 2000; Llobet-Brossa et al. 2002). 
JS-III
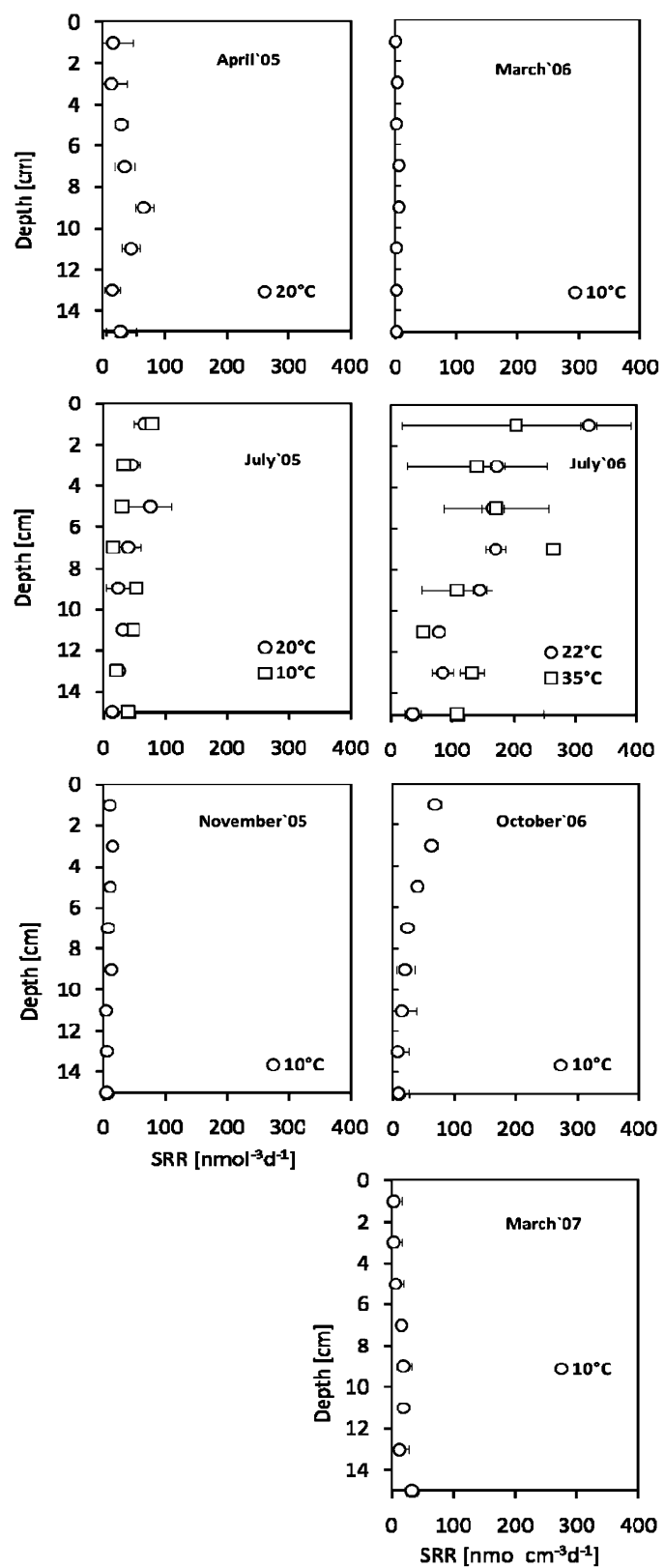

$100200 \quad 300 \quad 100$

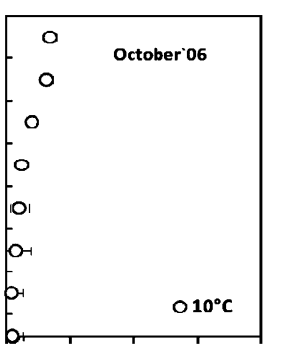

JS-I
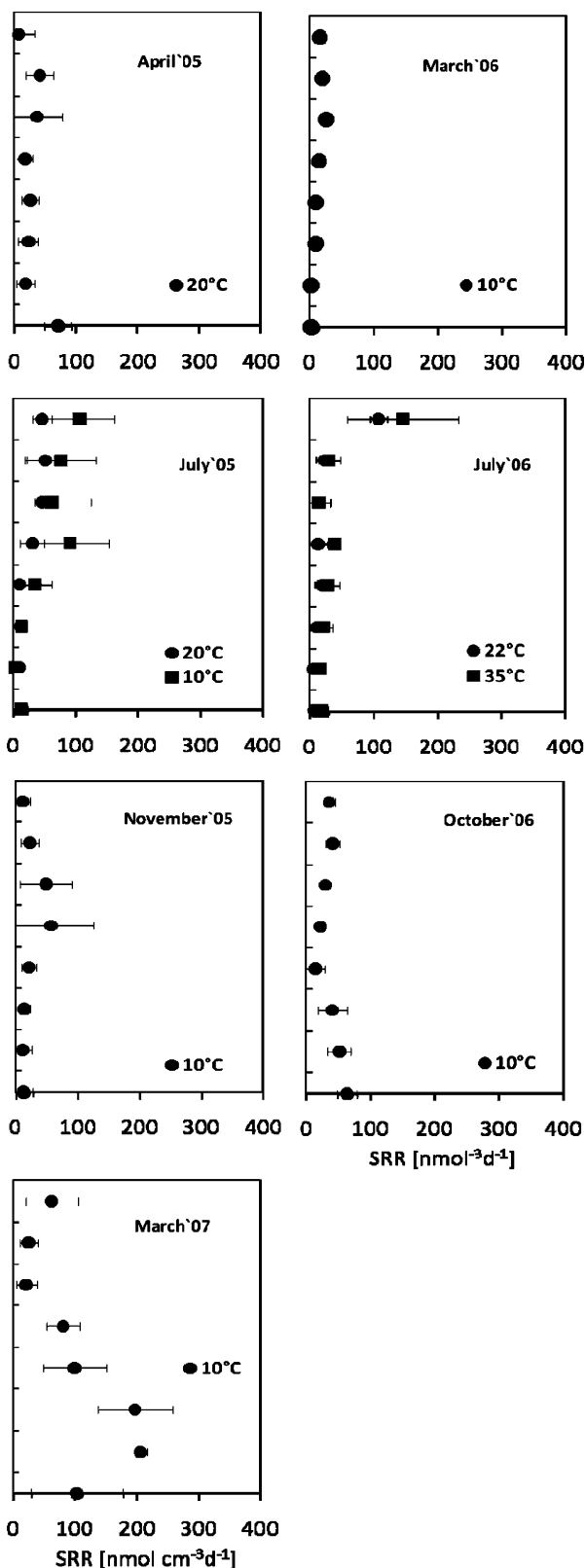

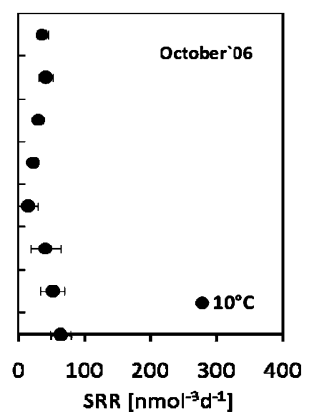

JS-I

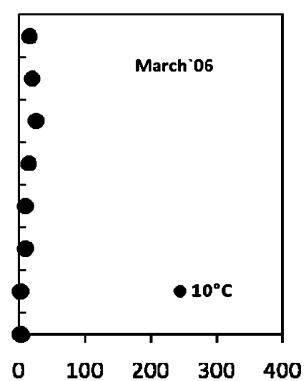

Fig. 6 (continued)

Seasonal trends for the sediment-specific SRR observed in the present study are in agreement with results from other tidal and salt marsh areas worldwide (Fig. 10). From the comparison, it becomes evident that the highest sulfate reduction rates are expected in salt marsh sediments as outlined above that are still under influence of temperature-induced seasonality. It must be kept in mind that the results from the Arrhenius equation describe the temperature dependence of the overall process using sulfate as the final electron acceptor and may be rate limited by, for instance, reactions making organic matter available for further microbial oxidation. The estimated $E_{\mathrm{a}}$ values indicate that the overall abilities of the sediments to react on temperature changes (e.g., amount and type of substrate; specific microbial community) differ for the investigated sediments types and seem to be the highest in the mud and mixed (N-II) flats (Fig. 8).

\subsubsection{Carbon mineralization via sulfate reduction in the study area}

From the results of the present study, the areal sulfate reduction rate for the whole study area can be estimated on a seasonal base. Monthly average temperature values measured by Bundesamt für Seeschifffahrt und Hydro- 
Fig. 7 Seasonal variations of depth-integrated sulfate reduction rates (top $15 \mathrm{~cm}$ ) obtained in the present study, interpolated, where necessary, to the average daily field temperature. Dashes Average surface water temperature data provided by $\mathrm{P}$. Loewe (BSH). Monthly minimum and maximum temperatures between 1995 and 2007 deviate from the mean values between $-0.1^{\circ} \mathrm{C}$ and $+4.7^{\circ} \mathrm{C}$

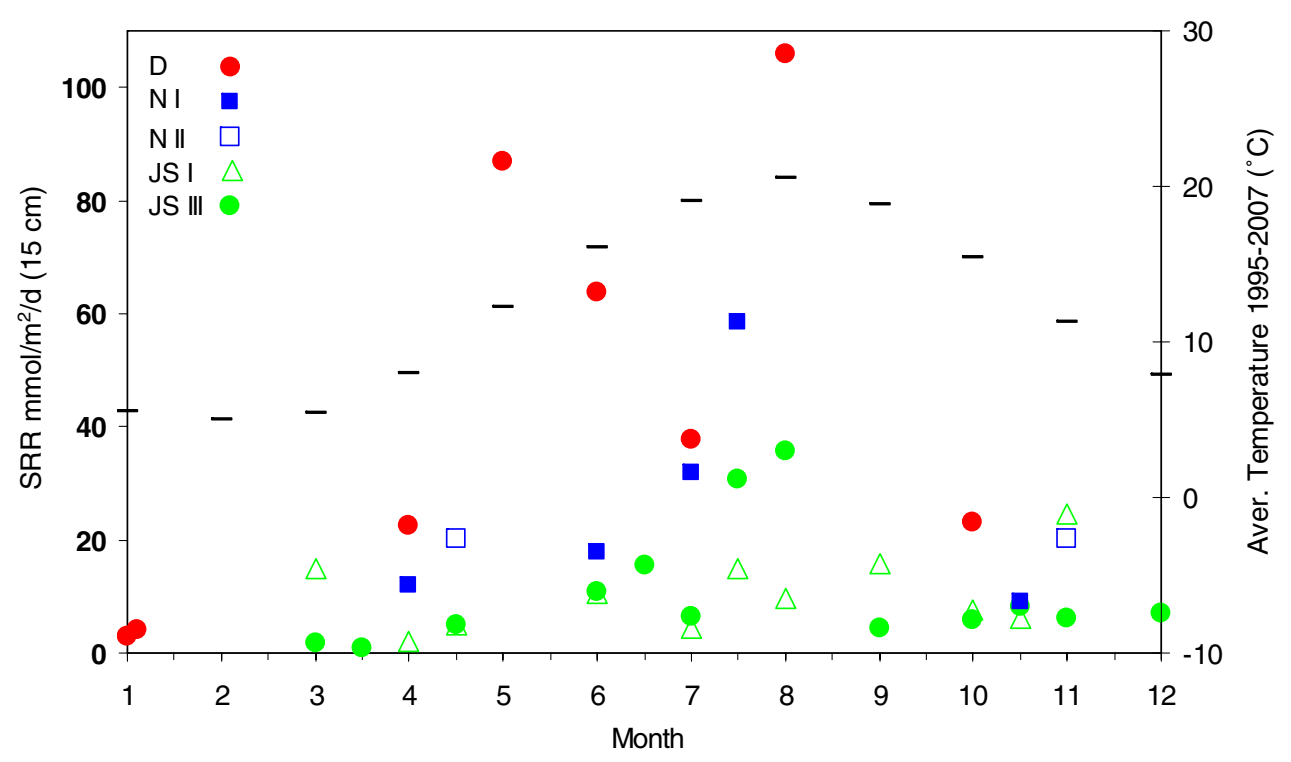

graphie (data provided by P. Loewe, BSH) in the German Bight (valid for the area east of $6.5^{\circ} \mathrm{E}$ and south of $55.5^{\circ} \mathrm{N}$ ) during the time period 1995 to 2007 showed pronounced seasonal variations with average spring, summer, autumn, and winter temperatures of $10^{\circ} \mathrm{C}, 20^{\circ} \mathrm{C}, 10^{\circ} \mathrm{C}$, and $5^{\circ} \mathrm{C}$ (Fig. 7). Based on the mapping of surface sediment distribution (Fig. 11) and the empirical site-specific temperature relations of SRR determined in the present study, the annual amounts of sulfate reduced in the top $15 \mathrm{~cm}$ surface sediments are calculated (Table 2). The sediment types used in Fig. 11 are separated in mudflats, mussel banks, mixed flats dark, sand flat, and light sand flat. Site D was used as representative for mudflats, site N-I for the mixed flats, and site JS-III for light sand flat. The mud accumulating potential of mussel beds leads typically to biogeochemical reactions similar to mudflat sites (Oenema 1990; Dittmann 1999). The mussel bank areas in the back-barrier tidal area therefore have been approximated by site D results. The previously investigated site Gröninger Plate is located in the area typified as dark sand flats (Fig. 1). SRR data were taken from previous measurements reported by Dellwig et al. (2007).

Two approaches were followed upon modeling: In the first approach, rates were calculated for the area of the intertidal flats only (Fig. 11). In the second approach, calculations have been carried out for the whole tidal area, including tidal channels. In this case, it was assumed that the main part of the subtidal channels is built of light sands. Temperatures and SRR used in the approximation are compiled in Table 2. According to the modeling results, about 39,122 , and 285 tons of sulfate are reduced per day in the top $15 \mathrm{~cm}$ of a $154-\mathrm{km}^{2}$ large tidal area (Fig. 10), during winter, spring or autumn, and summer time, respectively. Hence, areal benthic organic matter mineralization by microbial sulfate reduction increases during spring/autumn by a factor of about 2 and during summer by a factor of 7 when compared to winter time. The results correspond to an estimated benthic organic carbon mineralization rate via sulfate reduction of $78 \mathrm{~g} \mathrm{C} \mathrm{m}^{-2}$ year $^{-1}$. This value is within results reported for the Dutch Wadden Sea (Schröder 1983; Vosjan 1987). It should be noted that the overall rate will be slightly underestimated when higher mud contents for the bottoms of the subtidal part may have to be considered. Considering only the intertidal area, the estimated amounts of sulfate reduced daily are 36 (winter), 112 (spring or autumn), and 259 tons (summer), and the estimated annual benthic organic carbon mineralization rate via sulfate reduction is $60 \mathrm{~g} \mathrm{C} \mathrm{m}^{-2}$. These data can be compared to estimates for pelagic and benthic primary production in the Wadden Sea. A total production between 31 and $949 \mathrm{~g} \mathrm{C} \mathrm{m}^{-2}$ year $^{-1}$ was reported (Tillmann et al. 2000; Billerbeck et al. 2006). Thus, sulfate reduction accounts for a substantial part of organic matter oxidation. Billerbeck et al. (2006) estimated sulfate reduction to contribute for up to $25 \%$ of total benthic mineralization in the permeable sediments on the Janssand plate. Compared to temperature and organic matter contents as the main driving forces for SRR, also total cell numbers are positively correlated with the sulfate reducing activity (Fig. 12). It has to be kept in mind that temporal and spatial changes in surface sediment properties when compared to the sediment mapping shown in Fig. 11 may lead to corresponding shifts in the areal rates.

\subsection{Sulfide oxidation}

The difference between observed gross SRR and the pore water sulfate and sulfide gradients (Figs. 3 and 6) indicates intense reoxidation of sulfides via microbial and/or chemical sulfide reoxidation using oxygen, nitrate, or metal 


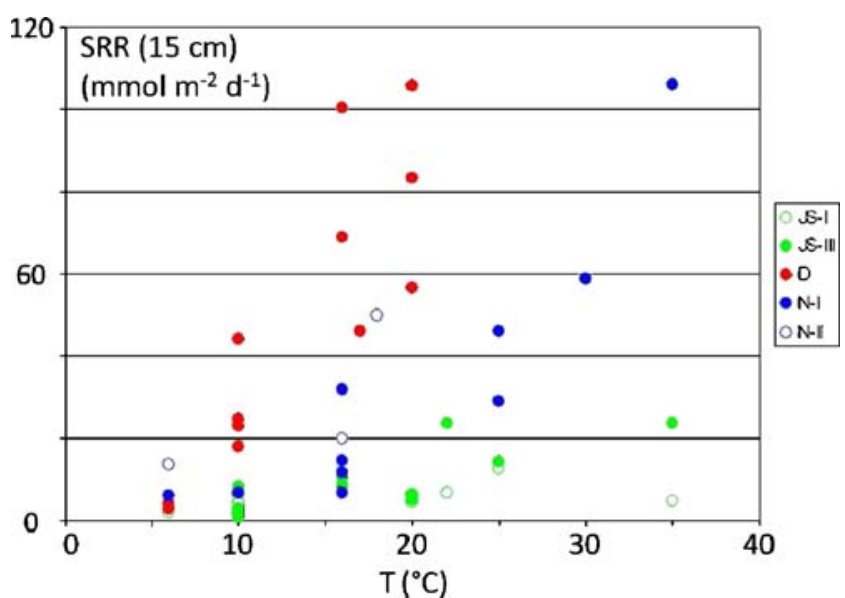

Fig. 8 Influence of temperature on integrated SRR (top $15 \mathrm{~cm}$ ) in the investigated different sediments. The N-II data are from Batel (2003) and Peters (2004) and the N-I (2001) data from Theune (2005)

oxides as electron acceptors (e.g., Jørgensen 2006). Since at least the sandy stations do not contain sufficient metal oxides to allow heterotrophic bacterial iron(III) and manganese (IV) reduction (Thamdrup 2000; Jensen et al. 2003), the accumulation of the divalent forms of these metals in pore waters indicates at least partial chemical sulfide oxidation via metal oxide reduction (e.g., Burdige and Nealson 1986; Aller and Rude 1988; Fossing and Jørgensen 1990; Dos Santos and Stumm 1992; Thamdrup et al. 1994; Moeslund et al. 1994; Böttcher et al. 2000). At site D, nitrate may penetrate a few millimeters into the sediment (Llobet-Brossa et al. 2002) and Mußmann et al. (2003) have observed sulfide-oxidizing gradient bacteria (Beggiatoa) in the top sediments. From downcore profiles of the relative AVS fraction at sites JS-I and JS-III (Fig. 13), it is seen that AVS is increasing with depth, due to decreasing sulfide oxidation, superimposed by pyrite formation at depth. In addition, during the July sampling campaign, more AVS was relatively recovered from the reduced surface sediment compared to JS-III sediments with an oxidized surface. The decrease of the relative AVS fraction at depth may be due to pyrite formation that is expected to be faster during summer time.

Direct indication for a fast sulfide reoxidation is obtained from the radiotracer incubations followed by a two-step distillation. The product of sediment core incubations for several hours with ${ }^{35} \mathrm{~S}$-labeled sulfate was recovered by up to $95 \%$ as $\mathrm{Cr}$ (II)-reducible sulfur, which is present mainly as elemental sulfur under these conditions. The first product of microbial sulfate reduction, hydrogen sulfide (AVS), was only a minor fraction. This indicates that hydrogen sulfide was efficiently oxidized to sulfur intermediates, likely via iron/manganese oxides and minor oxygen. The relation between metal and sulfur cycling will be discussed in detail elsewhere (Bosselmann et al., in preparation).

What is the consequence of sulfide oxidation for the long-term burial of reduced sedimentary sulfur in form of iron sulfides? Clearly not all of the produced sulfide is
A.

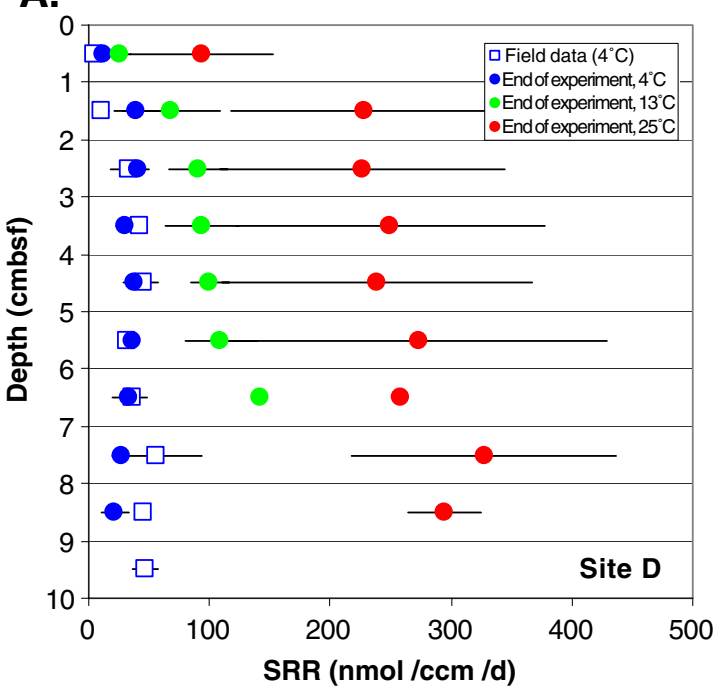

Fig. 9 a Effect of rising temperature on volumetric sulfate reduction rates on surface sediments at site D. Sediment was taken in winter (1/ 2000). Field data were measured at $4^{\circ} \mathrm{C}$ within hours after core retrival. Due to sediment incubations in flow chambers under lowflow conditions, the redox-cline rose as also seen in the shift of the SRR profile toward the surface. More experimental details can be found in Llobet-Brossa et al. (2000). It should be noted that under
B.

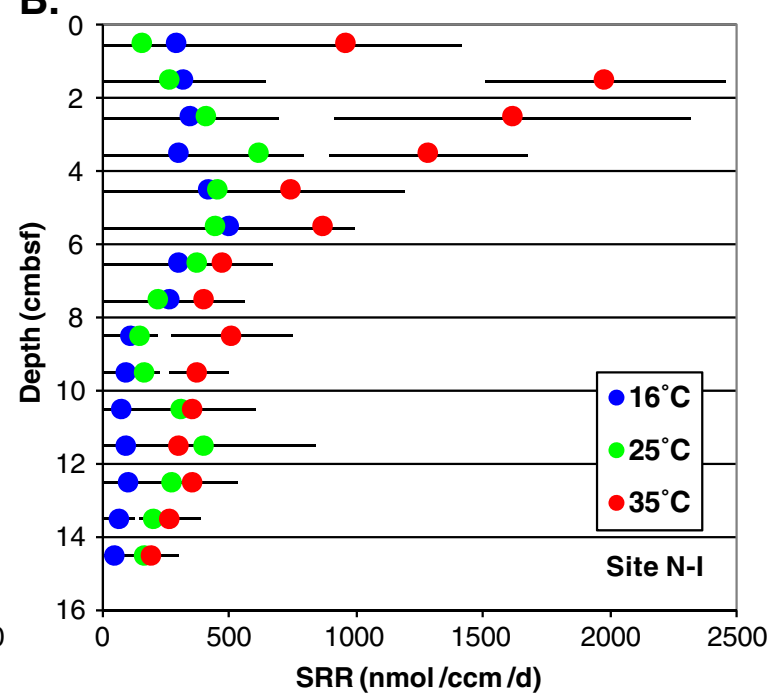

these incubation conditions, cell numbers changed too. b Effect of rising temperature on volumetric sulfate reduction rates during shortterm incubations of a surface sediment core from site N-I taken in July 2001 (Theune 2005). Intact sediment cores were preincubated for several hours at the three temperatures. Bars indicate range of measured SRR and result from two (a) and two to three (b) parallel incubations 

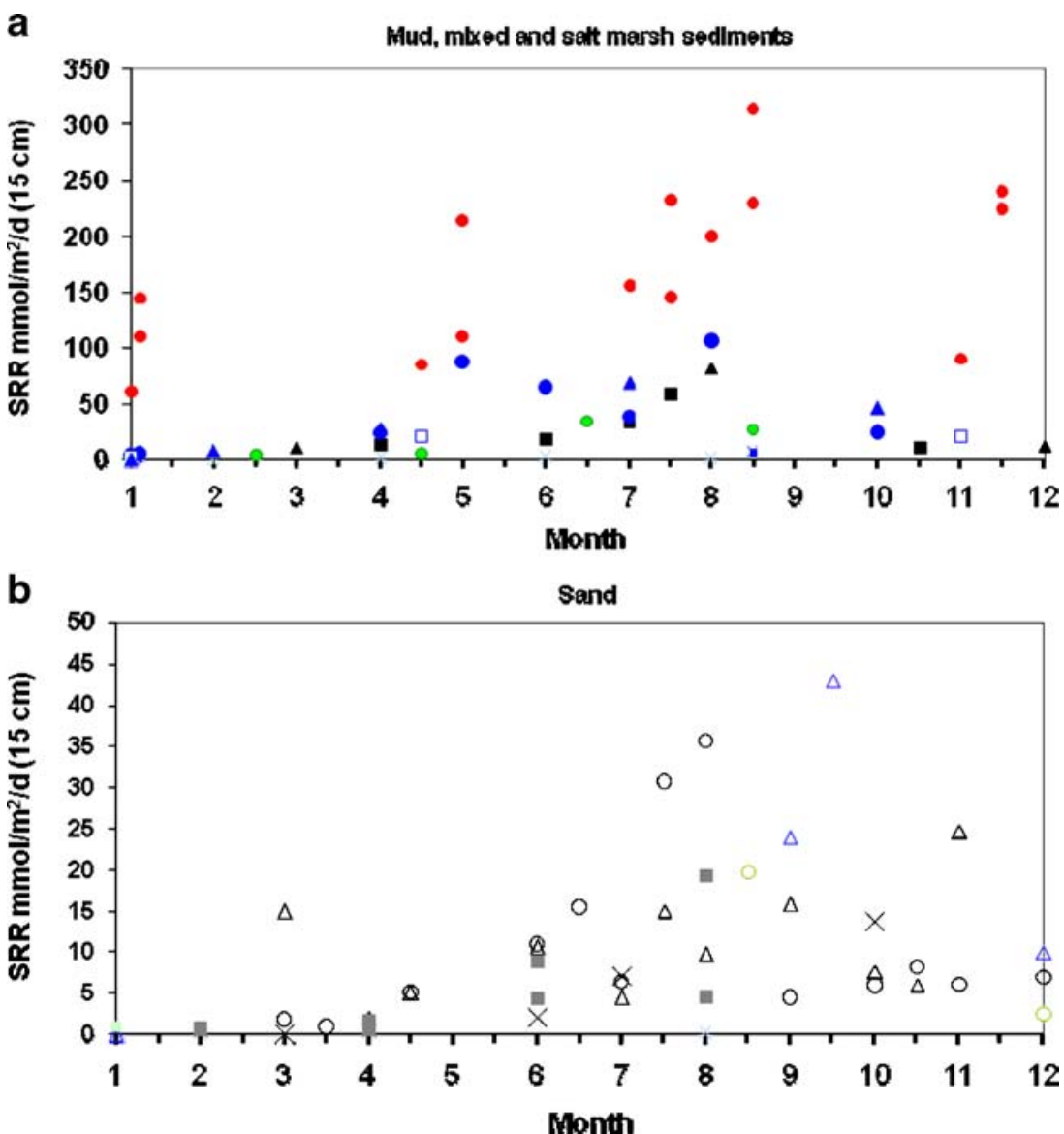

Fig. 10 Seasonal variations of areal sulfate reduction rates observed in the present study (taken from Fig. 7) compared to literature values for tidal and salt marsh sediments. Literature data are from taken Böttcher et al. (2004), de Beer et al. 2005, King (1988), Kostka et al.
(2002), Kristensen et al. (2000), Oenema (1990), Panutrakul (1993), and Werner et al. (2006). Red dots are salt marsh sediments (Kostka et al. 2002). Note different scales for the top and bottom parts

displaying complete physical mixing of the top $10 \mathrm{~cm}$ of the sediments but a change in age in deeper layers. We therefore assume that the onset of sandy sediments at depth is associated with at least one of the two events and may serve as an approximate time marker. An assumed maximum age (base 1998) of 30 years yields a sedimentation rate of about $3 \mathrm{~mm}$ per year. Considering a mean reduced sulfur content of $70 \mu \mathrm{mol} \mathrm{cm} \mathrm{cm}^{-3}$ (Böttcher et al. 2000) and an areal SRR of $7.3 \mathrm{~mol} \mathrm{~m}^{-2}$ year $^{-1}\left(10^{\circ} \mathrm{C}\right)$, a benthic preservation of about $3 \%$ of the formed hydrogen sulfide in form of iron sulfides in the top $10 \mathrm{~cm}$ is estimated. The consideration of an uncertainty in the estimated maximum age of \pm 10 years would lead to calculated sulfide retentions of about $5 \%$ that does not change the general conclusion. This high sulfide oxidation efficiency is close to findings by previous workers in other coastal sediments (e.g., Jørgensen 1982; ThodeAndersen and Jørgensen 1989; Thamdrup et al. 1994; Moeslund et al. 1994). The permeable sands are considered to be also very effective in sulfide cycling due to enhanced advection-induced oxygen penetration (de Beer et al. 2005; and ${ }^{137} \mathrm{Cs}$ measurements (Ferdelman, unpublished data) 

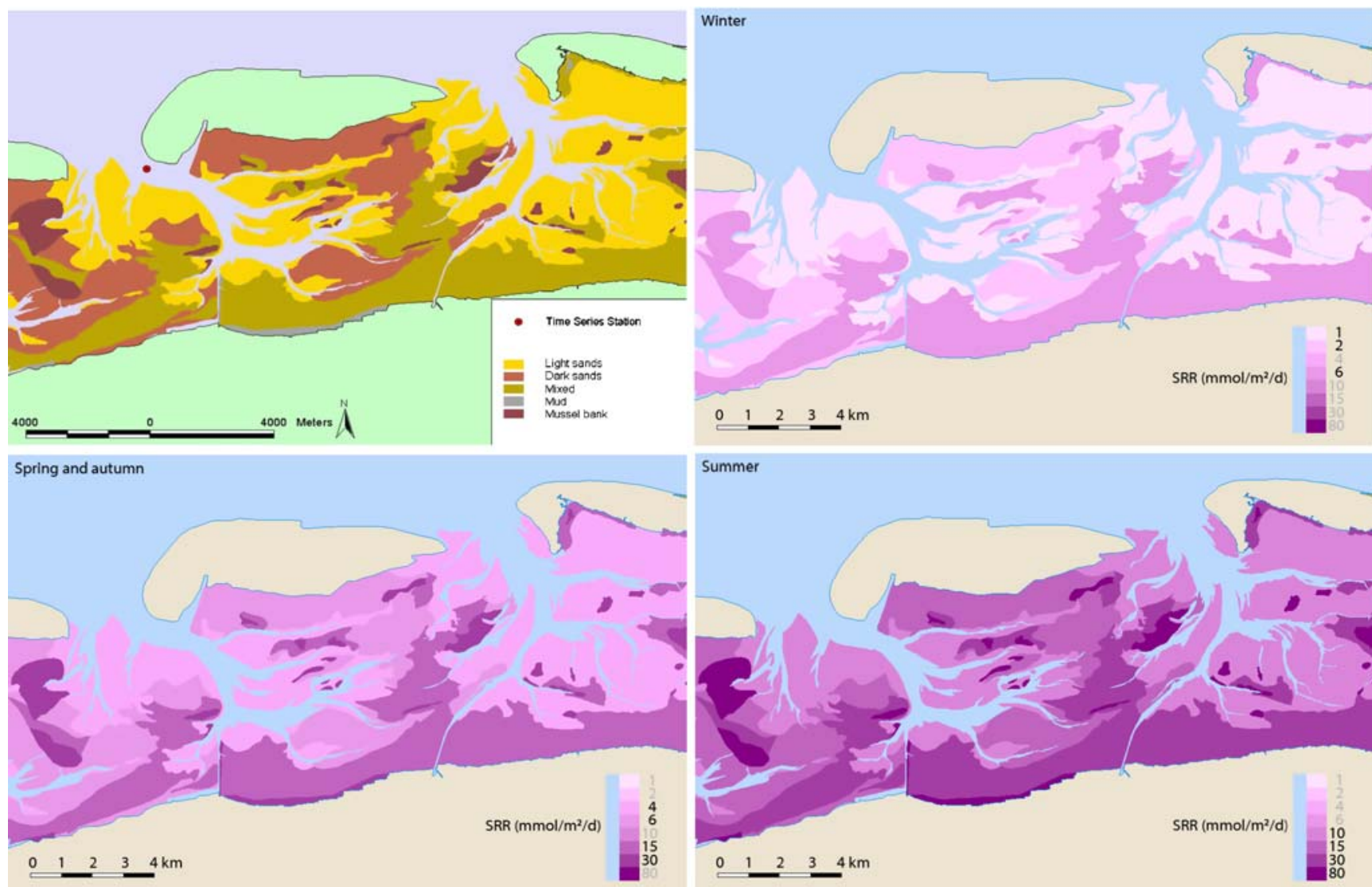

Fig. 11 Sediment-type distribution in the study area (in 1996) and resulting distribution of areal sulfate reduction rates for winter, spring/autumn, and summer situations. Considered average temperatures were $5^{\circ} \mathrm{C}, 10^{\circ} \mathrm{C}$, and $20^{\circ} \mathrm{C}$, respectively

Table 2 Compilation of parameters used in the calculations for Fig. 11

\begin{tabular}{|c|c|c|c|c|}
\hline & & $\operatorname{SRR}(15 \mathrm{~cm})\left(\mathrm{mmol} / \mathrm{m}^{2} /\right.$ day $)$ & Area $\left(\mathrm{km}^{2}\right)$ & Sulfate, reduced (kmol/day) \\
\hline \multirow[t]{7}{*}{ Winter } & Subtidal channels & 1 & 26.4 & 26 \\
\hline & Intertidal light sands & 1 & 52.8 & 53 \\
\hline & Intertidal dark sands & 2 & 30.0 & 60 \\
\hline & Mixed flats & 6 & 37.2 & 223 \\
\hline & Mudflats and & & & \\
\hline & Mussel banks & 6 & 7.2 & 43 \\
\hline & Sum & & & 406 \\
\hline \multirow[t]{6}{*}{ Spring/autumn } & Subtidal channels & 4 & 26.4 & 106 \\
\hline & Intertidal light Sands & 4 & 52.8 & 211 \\
\hline & Intertidal dark sands & 6 & 30.0 & 180 \\
\hline & Mixed flats & 15 & 37.2 & 558 \\
\hline & Mudflats and Mussel banks & 30 & 7.2 & 216 \\
\hline & Sum & & & 1,271 \\
\hline \multirow[t]{6}{*}{ Summer } & Subtidal channels & 10 & 26.4 & 264 \\
\hline & Intertidal light sands & 10 & 52.8 & 528 \\
\hline & Intertidal dark sands & 16 & 30.0 & 480 \\
\hline & Mixed flats & 30 & 37.2 & 1,116 \\
\hline & Mudflats and mussel banks & 80 & 7.2 & 576 \\
\hline & Sum & & & 2,964 \\
\hline
\end{tabular}




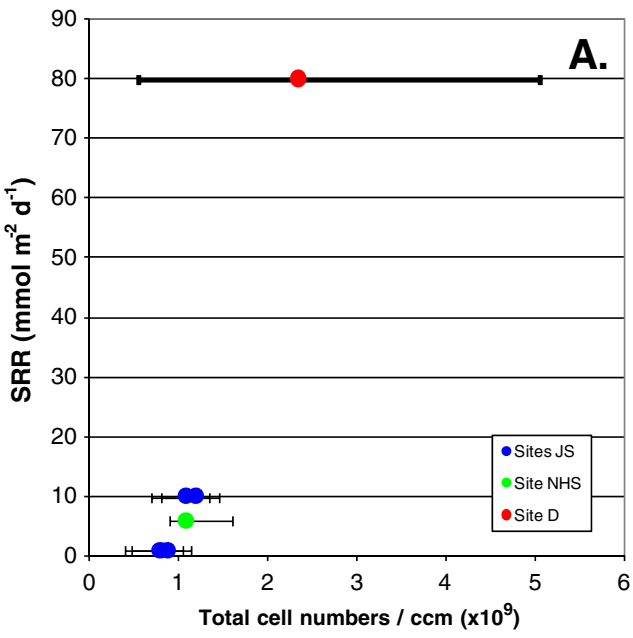

Fig. 12 Depth-integrated sulfate reduction rates in top $15 \mathrm{~cm}$ as a function of total cell numbers (DAPI counts) and the range of TOC contents. a Summer and winter SRR are from Table 2, and average total cell counts in the top $10 \mathrm{~cm}$ for station JS (July 2005 and March

Werner et al. 2003, 2006) and dynamical metal oxide cycling (Panutrakul 1993; Bosselmann et al., in preparation).

\section{Conclusions}

The role of microbial sulfate reduction on organic matter oxidation was studied quantitatively in different temperate intertidal surface sediments of the German Wadden Sea

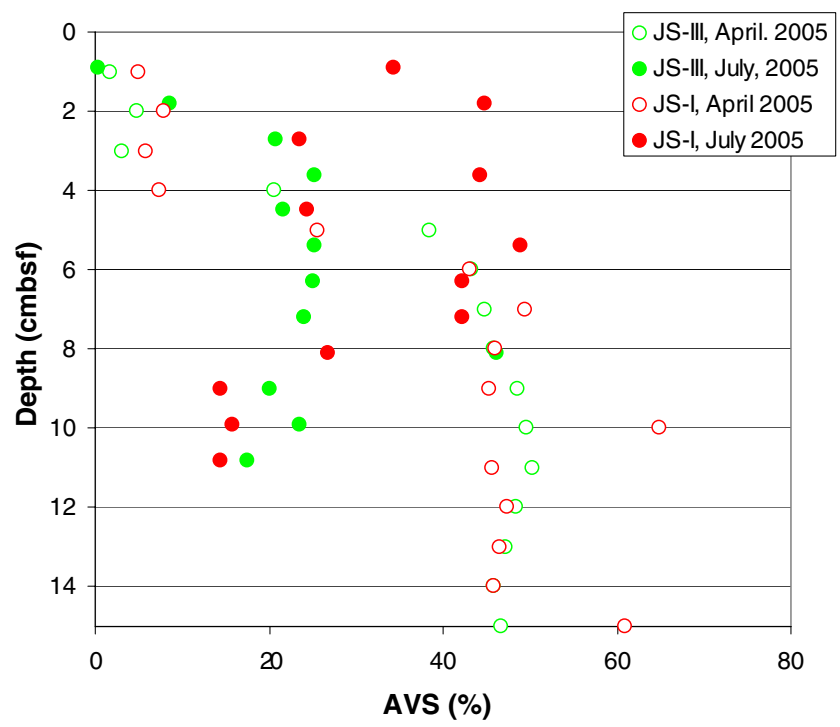

Fig. 13 Percentage of the reduced inorganic sulfur fraction recovered as acid volatile sulfide $(A V S)$ in sediment cores taken at stations JS-I and JS-III at two different dates in 2005. Decrease of relative AVS content at depth may indicate transformation into pyrite, which seems to be enhanced during summer time

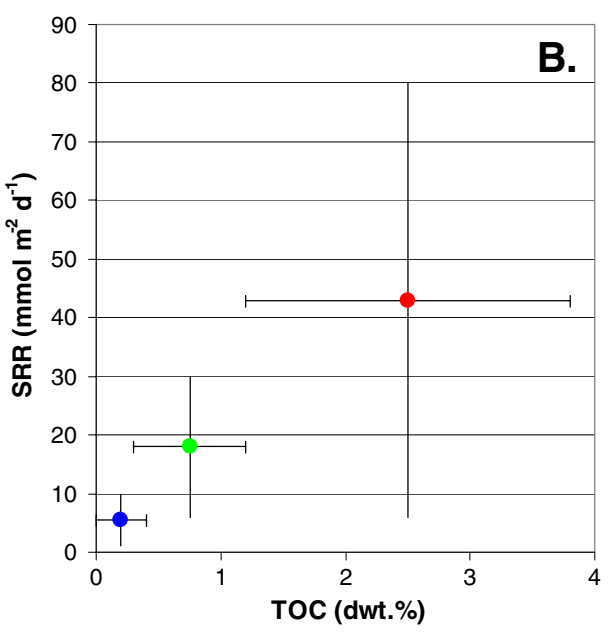

2006), N-1, and D are from Böer et al. (in preparation), Ishii (2002, personal communication), and Llobet-Brossa et al. (2002), respectively. Bars indicate range with minimum and maximum values. b Ranges for TOC and SRR data are taken from Table 2

(southern North Sea) on a seasonal base. Integrated areal sulfate reduction rates in the top $15 \mathrm{cmbsf}$ showed the highest rates in mud and mixed flat sediments and lower rates measured in sands at the same time. This is due to the superimposing influences of substrate availability and quality as well as temperature on the overall anaerobic mineralization process. In conclusion, the present study demonstrates the importance of both temperature and organic matter load on the rates of sulfate reduction in the surface sediments on a seasonal scale. Considering the obtained temperature dependence and influence of organic contents, areal rates for the intertidal back-barrier area were calculated for the different seasons. According to the modeling results, the importance of areal benthic organic matter mineralization by microbial sulfate reduction increases during spring/autumn by a factor of about 2 and during summer by a factor of 7 when compared to winter. Further studies are required for areal estimates of aerobic mineralization processes, benthic primary production, and will have to consider the influence of sediment reworking on the energy and material transfers upon benthic-pelagic coupling in form of organic matter and metabolite transport.

Acknowledgments We wish to acknowledge the laboratory support by D. Benesch, S. Klein, M. Meyer, R. Rosenberg, A. Schipper, and, in particular, S. Lilienthal, the field support during the cruises to the Janssand area by the skippers and crews of several Dutch tjalks (in particular deep thanks go to Ronald, Iso, and Tatjana), and P. Bird, E. Walpersdorf, and S. Jansen for organizing the Janssand field trips. MEB wishes to thank T. Höpner, B. Oelschläger, and I. Langner for the enthusiastic introduction into the Wadden Sea ecology and his excellent students S. Batel, F. Ebersbach, A. Lang, L. Peters, and A. Theune for 
their shared enthusiasm. He also thanks T.M.C. Böttcher for his help in the field and E. Costello, C. Hynde \& The Pretenders, and P. Cole and P. Gabriel for musical inspiration. We further wish to thank A. Batholomä, H.-J. Brumsack, H. Cypionka, O. Dellwig, T. Ferdelman, B.W. Flemming, J. Ingwersen, and J.-W. Schröder for stimulating discussions. G. Gerdes (ICBM Wilhelmshaven) and H.-J. Brumsack (ICBM Oldenburg) kindly provided access to analytical facilities. MEB dedicates this publication to E. Biermann. The study was supported by Deutsche Forschungsgemeinschaft during DFG research group "BioGeoChemistry of Tidal Flats" (JO 307/4, BO 1584/4), the Max Planck Society, and the Leibniz IOW. We wish to thank J. Rullkötter for the excellent coordination of the research group and B.B. Jørgensen for his continuous support of the project. Very special thanks go to R. Amann, D. de Beer, M. Hüttel, and H. Roy for the good scientific collaboration and team work. Last but not the least, we wish to thank two anonymous reviewers and our associate editor M. Simon for their invaluable and very detailed comments on the manuscript.

Open Access This article is distributed under the terms of the Creative Commons Attribution Noncommercial License which permits any noncommercial use, distribution, and reproduction in any medium, provided the original author(s) and source are credited.

\section{References}

Aller RC, Rude PD (1988) Complete oxidation of solid phase sulfides by manganese and bacteria in anoxic marine sediments. Geochim Cosmochim Acta 52:751-765. doi:10.1016/0016-7037(88) 90335-3

Batel S (2003) Biogeochemische Umsatzprozesse in einem tidalen Oberflächensediment der südlichen Nordsee. Diploma thesis, University of Oldenburg, $112 \mathrm{pp}$

Beck M, Dellwig O, Liebezeit G, Schnetger B, Brumsack H-J (2008a) Spatial and seasonal variations of sulphate, dissolved organic carbon, and nutrients in deep pore waters of intertidal flat sediments. Estuar Coast Shelf Sci 79:307-316. doi:10.1016/j. ecss.2008.04.007

Beck M, Dellwig O, Schnetger B, Brumsack H-J (2008b) Cycling of trace metals $(\mathrm{Mn}, \mathrm{Fe}, \mathrm{Mo}, \mathrm{U}, \mathrm{V}, \mathrm{Cr}$ ) in deep pore waters of intertidal flat sediments. Geochim Cosmochim Acta 72:28222840. doi:10.1016/j.gca.2008.04.013

Benner SG, Blowes DW, Ptacek CJ, Mayer KU (2002) Rates of sulfate reduction and metal sulfide precipitation in a permeable reactive barrier. Appl Geochem 17:301-320. doi:10.1016/S08832927(01)00084-1

Berner RA (1989) Biogeochemical cycles of carbon and sulfur and their effect on atmospheric oxygen over phanerozoic time. Palaeogeogr Palaeoclimatol Palaeoecol 75:97-122. doi:10.1016/ 0031-0182(89)90186-7

Berner RA, Westrich JT (1985) Bioturbation and the early diagenesis of carbon and sulfur. Am J Sci 285:193-206

Billerbeck M, Werner U, Polerecky L, Walpersdorf E, de Beer D, Hüttel M (2006) Surficial and deep pore water circulation governs spatial and temporal scales of nutrient recycling in intertidal sand flat sediment. Mar Ecol Prog Ser 326:61-76. doi:10.3354/meps326061

Billerbeck M, Roy H, Bosselmann K, Hüttel M (2007) Benthic photosynthesis in submerged Wadden Sea intertidal flats. Estuar Coast Shelf Sci 71:704-716. doi:10.1016/j.ecss.2006.09.019

Boetius A, Ferdelman T, Lochte K (2000) Bacterial activity in sediments of the deep Arabian Sea in relation to vertical flux. Deep Sea Res Part II Top Stud Oceanogr 47:2835-2875. doi:10.1016/S0967-0645(00)00051-5
Böttcher ME (2003) Schwarze Flecken und Flächen im Wattenmeer. In: Lozàn JL, Rachor E, Reise K, Sündermann J, Westernhagen VH (eds) Warnsignale aus der Nordsee \& Wattenmeer-Eine aktuelle Umweltbilanz. Wissenschaftliche Auswertungen, Hamburg, pp 193-195

Böttcher ME, Oelschläger B, Höpner T, Brumsack H-J, Rullkötter J (1998) Sulfate reduction related to the early diagenetic degradation of organic matter and "black spot" formation in tidal sandflats of the German Wadden Sea: Stable isotope $\left({ }^{13} \mathrm{C},{ }^{34} \mathrm{~S}\right.$, ${ }^{18} \mathrm{O}$ ) and other geochemical results. Org Geochem 29:15171530. doi:10.1016/S0146-6380(98)00124-7

Böttcher ME, Hespenheide B, Llobet-Brossa E, Beardsley C, Larsen O, Schramm A, Wieland A, Böttcher G, Berninger UG, Amann R (2000) The biogeochemistry, stable isotope geochemistry, and microbial community structure of a temperate intertidal mudflat: an integrated study. Cont Shelf Res 20:1749-1769. doi:10.1016/ S0278-4343(00)00046-7

Böttcher ME, Hespenheide B, Brumsack HJ, Bosselmann K (2004) Stable isotope biogeochemistry of the sulfur cycle in modern marine sediments: I. Seasonal dynamics in a temperate intertidal sandy surface sediment. Isotopes Environ Health Stud 40:267283. doi:10.1080/10256010410001678071

Böttcher ME, Al-Raei AM, Hilker Y, Heuer V, Hinrichs K-U, Segl M (2007a) Methane and organic matter as sources for excess carbon dioxide in intertidal surface sands: biogeochemical and stable isotope evidence. Geochim Cosmochim Acta 71:A111

Böttcher ME, Brumsack H-J, Dürselen C-D (2007b) The isotopic composition of modern seawater sulfate: I. Coastal waters with special regard to the North Sea. J Mar Syst 67:73-82. doi:10.1016/j.jmarsys.2006.09.006

Bosselmann K, Böttcher ME (2008) A novel approach to sulfate reduction rate determinations considering temperature fluctuations in intertidal top sediments. Limnol Oceanogr Methods (in press)

Boudreau BP, Jørgensen BB (eds) (2001) The benthic boundary layer. Transport processes and biogeochemistry. Oxford University Press, Oxford, p 404

Burdige DJ, Nealson KH (1986) Chemical and microbiological studies on sulfide-mediated manganese reduction. Geomicrobiol J 4:361387. doi:10.1080/01490458609385944

Canfield DE (1989) Reactive iron in marine sediments. Geochim Cosmochim Acta 53:619-632. doi:10.1016/0016-7037(89)90005-7

Canfield DE, Thamdrup B, Hansen JW (1993) The anaerobic degradation of organic-matter in danish coastal sediments - iron reduction, manganese reduction, and sulfate reduction. Geochim Cosmochim Acta 57:3867-3883. doi:10.1016/0016-7037(93) 90340-3

Chang TS, Flemming BW, Bartholomä A (2007) Distinction between sortable silts and aggregated particles in muddy intertidal sediments of the southern North Sea. Sediment Geol 202:453-463. doi:10.1016/j.sedgeo.2007.03.009

Cline JD (1969) Spectrophotometric determination of hydrogen sulfide in natural waters. Limnol Oceanogr 14:454-458

D'Andrea AF, Aller RC, Lopez GR (2002) Organic matter flux and reactivity on a South Carolina sandflat: the impacts of pore water advection and macrobiological structures. Limnol Oceanogr 47:1056-1070

de Beer D, Wenzhöfer F, Ferdelman TG, Boehme SE, Hüttel M, van Beusekom JEE, Böttcher ME, Musat N, Dubilier N (2005) Transport and mineralization rates in North Sea sandy intertidal sediments, Sylt-Romo Basin, Wadden Sea. Limnol Oceanogr 50:113-127

DeFlaun MF, Mayer M (1983) Relationships between bacteria and grain surfaces in intertidal sediments. Limnol Oceanogr 28:873-881

Delafontaine MT, Bartholomä A, Flemming BW, Kurmis R (1996) Volume-specific dry POC mass in surficial intertidal sediments: a 
comparison between biogenic muds and adjacent sand flats. Senckenb Marit 26:167-178

Dellwig O, Bosselmann K, Kölsch S, Hentscher M, Hinrichs J, Böttcher ME, Reuter R, Brumsack H-J (2007) Sources and fate of manganese in a tidal basin of the German Wadden Sea. J Sea Res 57:1-18. doi:10.1016/j.seares.2006.07.006

Dittmann S (ed) (1999) The Wadden Sea Ecosystem. Stability properties and mechanisms. Springer, New York

Dos Santos M, Stumm W (1992) The reductive dissolution of iron(III) (hydr) oxides by hydrogen sulfide. Langmuir 8:1671-1676

Flemming BW, Ziegler K (1995) High-resolution grain size distribution patterns and textural trends in the backbarrier tidal flats of Spiekeroog Island (southern North Sea). Senckenb Marit 26:1-24

Fossing H, Jørgensen BB (1989) Measurement of bacterial sulfate reduction in sediments - evaluation of a single-step chromium reduction method. Biogeochemistry 8:205-222. doi:10.1007/ BF00002889

Fossing H, Jørgensen BB (1990) Oxidation and reduction of radiolabeled inorganic sulfur compounds in an estuarine sediment, Kysing Fjord, Denmark. Geochim Cosmochim Acta 54:27312742. doi:10.1016/0016-7037(90)90008-9

Freese E, Köster J, Rullkötter J (2008) Origin and composition of organic matter in tidal flat sediments from the German Wadden Sea. Org Geochem 39:820-829. doi:10.1016/j.orggeo chem.2008.04.023

Freitag T, Klenke T, Krumbein WE, Gerdes G, Prosser JI (2003) Effect of anoxia and high sulphide concentrations on heterotrophic microbial communities in reduced surface sediments (black spots) in sandy intertidal flats of the German Wadden Sea. FEMS Microbiol Ecol 44:291-301. doi:10.1016/S0168-6496(03) 00076-X

Froelich PN, Klinkhammer GP, Bender ML, Luedtke NA, Heath GR, Cullen D, Dauphin P, Hammond D, Hartman B, Maynard V (1979) Early oxidation of organic matter in pelagic sediments of the eastern equatorial Atlantic: suboxic diagenesis. Geochim Cosmochim Acta 43:1075-1090. doi:10.1016/0016-7037(79)90095-4

Graf G, Rosenberg R (1997) Bioresuspension and biodeposition: a review. J Mar Syst 11:269-278. doi:10.1016/S0924-7963(96)00126-1

Hansen LS, Holmer M, Blackburn TH (1993) Mineralization of organic nitrogen and carbon (fish food) added to anoxic sediment microcosms: role of sulphate reduction. Mar Ecol Prog 102:199204. doi: $10.3354 /$ meps 102199

Henrichs SM, Reeburgh WS (1987) Anaerobic mineralization of marine sedimenst organic matter. Rates and the role of anaerobic processes in the carbon economy. Geomicrobiol J 5:191-238. doi:10.1080/01490458709385971

Hertweck G (1995) Distribution patterns of characteristic sediment bodies and benthos populations in the Spiekeroog backbarrier tidal flat area, southern North Sea. Results of survey of tidal flat structure 1988-1992. Senckenb Marit 26:81-94

Hespenheide B (1999) Biogeochemische und isotopengeochemische Untersuchungen in Schlick- und Sandwatt-Sedimenten der Nordsee. Diploma thesis, University of Bremen

Hinck W (1967) Kampf gegen Ölpest am Dangaster Strand. Nordwestzeitung 25(4):1967

Hines ME, Jones GE (1985) Microbial biogeochemistry in the sediments of Great Bay, New Hampshire. Estuar Coast Shelf Sci 20:729-742. doi:10.1016/0272-7714(85)90029-0

Howarth RW, Giblin A (1983) Sulfate reduction in the salt marshes at Sapelo Island, Georgia. Limnol Oceanogr 28:70-82

Hubas C, Davoult D, Cariou T, Artigas L-F (2006) Factors controlling benthic metabolism during low tide along a granulometric gradient in an intertidal bay (Roscoff Aber Bay, France). Mar Ecol Prog Ser 326:53-68. doi:10.3354/meps316053

Hüttel M, Rusch A (2000) Transport and degradation of phytoplankton in permeable sediment. Limnol Oceanogr 45:534-549
Hüttel M, Ziebis W, Forster S (1996) Flow-induced uptake of particulate matter in permeable sediments. Limnol Oceanogr 41:309-322

Ingwersen J (2005) Nah am Wasser. Aufbau Taschenbuch, Berlin, p 312

Irion G (1994) Morphological, sedimentological and historical evolution of Jade Bay, southern North Sea. Senckenb Marit 24:171-186

Ishii K, Mussmann M, MacGregor BJ, Amann R (2004) An improved fluorescence in situ hybridization protocol for the identification of bacteria and archaea in marine sediments. FEMS Microbiol Ecol 50:203-212. doi:10.1016/j.femsec.2004.06.015

Jansen S, Walpersdorf E, Werner U, Billerbeck M, Böttcher ME, de Beer D (2009) Functioning of intertidal flats inferred from temporal and spatial dynamics of $\mathrm{O}_{2}, \mathrm{H}_{2} \mathrm{~S}$ and $\mathrm{pH}$ in their surface sediment. Ocean Dynamics (in press)

Jensen MM, Thamdrup B, Rysgaard S, Holmer M, Fossing H (2003) Rates and regulation of microbial iron reduction in sediments of the Baltic-North Sea transition. Biogeochemistry 65:295-317

Jørgensen BB (1977) The sulfur cyle of a coastal marine sediment (Limfjorden, Denmark). Limnol Oceanogr 22:814-832

Jørgensen BB (1982) Mineralization of organic matter in the sea bedthe role of sulphate reduction. Nature 296:643-645. doi:10.1038/ $296643 \mathrm{a} 0$

Jørgensen BB (2006) Bacteria and marine biogeochemistry. In: Schulz HD, Zabel M (eds) Marine geochemistry. Springer, New York, pp 169-206

Jørgensen BB, Weber A, Zopfi J (2001) Sulfate reduction and anaerobic methane oxidation in Black Sea sediments. Deep-Sea Res 48:2097-2120. doi:10.1016/S0967-0637(01)00007-3

Kallmeyer J, Ferdelman TG, Weber A, Fossing H, Jørgensen BB (2004) A cold chromium distillation procedure for radiolabeled sulfide applied to sulfate reduction measurements. Limnol Oceanogr Methods 2:171-180

King GM (1983) Sulfate reduction in Georgia salt marsh soils: an evaluation of pyrite formation by use of ${ }^{35} \mathrm{~S}$ and ${ }^{55} \mathrm{Fe}$ tracers. Limnol Oceanogr 28:987-995

King GM (1988) Patterns of sulfate reduction and the sulfur cycle in a South Carolina salt marsh. Limnol Oceanogr 33:376-390

Kostka JE, Luther GW (1994) Partitioning and speciation of solid phase iron in saltmarsh sediments. Geochim Cosmochim Acta 58:1701-1710. doi:10.1016/0016-7037(94)90531-2

Kostka JE, Roychoudhury A, Van Cappellen P (2002) Rates and controls of anaerobic microbial respiration across spatial and temporal gradients in saltmarsh sediments. Biogeochemistry 60:49-76. doi:10.1023/A:1016525216426

Kristensen E, Bodenbender J, Jensen MH, Rennenberg H, Jensen KM (2000) Sulfur cycling of intertidal Wadden Sea sediments (Königshaven, Island of Sylt, Germany): sulfate reduction and sulfur gas emission. J Sea Res 43:93-104. doi:10.1016/S13851101(00)00007-1

Llobet-Brossa E, Böttcher ME, Gieseke A, Mussmann M, Schramm A, Rossello-Mora R, Amann R (2000) Seasonal microbial community dynamics and activity of the temperate tidal sediment of Dangast. In: Llobet-Brossa E, Microbial community structure and dynamics of Wadden Sea sediments (Dangast). PhD thesis, University of Bremen, pp 95-128

Llobet-Brossa E, Rabus R, Böttcher ME, Könneke M, Finke N, Schramm A, Meyer RL, Grötzschel S, Rossello-Mora R, Amann R (2002) Community structure and activity of sulfate-reducing bacteria in an intertidal surface sediment: a multi-method approach. Aquat Microb Ecol 29:211-226. doi:10.3354/ ame029211

Mayer LM, Rhaim PT, Guerin W, Macko SA, Watling L, Anderson FE (1985) Biological and granulometric controls on organic matter of an intertidal mudflat. Estuar Coast Shelf Sci 20:491-503. doi:10.1016/0272-7714(85)90091-5 
Moeslund L, Thamdrup B, Jørgensen BB (1994) Sulfur and iron cycling in a coastal sediment - radiotracer studies and seasonal dynamics. Biogeochemistry 27:129-152

Morse JW (1999) Sulfides in sandy sediments: new insights on the reactions responsible for sedimentary pyrite formation. Aquat Geochem 5:75-85. doi:10.1023/A:1009620021442

Musat N, Werner U, Knittel K, Kolb S, Dodenhof T, van Beusekom JEE, de Beer D, Dubilier N, Amann R (2006) Microbial community structure of sandy intertidal sediments in the North Sea, Sylt-Romo Basin, Wadden Sea. Syst Appl Microbiol 29:333-348. doi:10.1016/j.syapm.2005.12.006

Mußmann M, Schulz HN, Strotmann B, Kjaer T, Nielsen LP, Rossello-Mora RA, Amann R, Jørgensen BB (2003) Phylogeny and distribution of nitrate-storing Beggiatoa spp in coastal marine sediments. Environ Microbiol 5:523-533. doi:10.1046/ j.1462-2920.2003.00440.x

Oelschläger B (2002) Extremsituationen des Porenwasserchemismus in Sandwattsediment. PhD thesis, University of Oldenburg, $124 \mathrm{pp}$

Oenema O (1990) Sulfate reduction in fine-grained sediments in the Eastern Scheldt, southwest Netherlands. Biogeochem 9:53-74. doi:10.1007/BF00002717

Panutrakul S (1993) Impact of sulfur cycle on the mobilization of heavy metals in intertidal flat sediments. $\mathrm{PhD}$ thesis, Vrije Universiteit Brussel, $197 \mathrm{pp}$

Pasche T, Brockamp O, Clauer N (2008) Varied pathways of riverborne clay minerals in a near-shore marine region: a case study of sediments from the Elbe- and Weser rivers, and the SE North Sea. Estuar Coast Shelf Sci 78:563-575. doi:10.1016/j. ecss.2008.01.016

Peters L (2004) Zur Biogeochemie eines Sedimentkerns aus dem Mischwatt der südlichen Nordsee. Diploma thesis, University of Oldenburg, $113 \mathrm{pp}$

Pomeroy LR, Wiebe WJ (2001) Temperature and substrates as interactive limiting factors for marine heterotrophic bacteria. Aquat Microb Ecol 23:187-204. doi:10.3354/ame023187

Pyzik AJ, Sommer SE (1981) Sedimentary iron monosulfides: kinetics and mechanism of formation. Geochim Cosmochim Acta 45:687-698. doi:10.1016/0016-7037(81)90042-9

Reineck HE (1982) Das Watt, Ablagerungs- und Lebensraum. Waldemar Kramer, Frankfurt

Rullkötter J (2006) Organic matter: the driving force for early diagenesis. In: Schulz HD, Zabel M (eds) Marine geochemistry. Springer, New York, pp 125-168

Rusch A, Töpken H, Böttcher ME, Höpner T (1998) Recovery from black spots: results of a loading experiment in the Wadden Sea. J Sea Res 40:205-219. doi:10.1016/S1385-1101(98)00030-6

Saager PM, Sweerts JP, Ellermeijer HJ (1990) A simple pore-water sampler for coarse, sandy sediments of low porosity. Limnol Oceanogr 35:747-751

Schröder HGJ (1983) Anaerobe mineralisatie. In: Biologisch Onderzoek Eems-Dollard Estuarium, BOEDE-group. BOEDE publicaties en verslagen 1983-1

Schubert C, Ferdelman T, Strothmann B (2000) Organic matter composition and sulfate reduction rates in sediments off Chile. Org Geochem 31:351-361. doi:10.1016/S0146-6380(00)00005-X

Shum KT, Sundby B (1996) Organic matter processing in continental shelf sediments - the subtidal pump revisited. Mar Chem 53:8187. doi:10.1016/0304-4203(96)00014-X

Skyring GW (1987) Sulfate reduction in coastal ecosystems. Geomicrobiol J 5:295-374. doi:10.1080/01490458709385974

Stanev EV, Wolff JO, Burchard H, Bolding K, Flöser G (2003) On the circulation in the East Frisian Wadden Sea. Numerical modelling and data analysis. Ocean Dyn 53:27-51. doi:10.1007/s10236002-0022-7

Stevens H, Brinkhoff T, Simon M (2005) Composition of free-living, aggregate-associated and sediment surface-associated bacterial communities in the German Wadden Sea. Aquat Microb Ecol 38:15-30. doi:10.3354/ame038015

Stookey LL (1970) Ferrozine - a new spectrometric reagent for iron. Anal Chem 42:779-781. doi:10.1021/ac60289a016

Thamdrup B (2000) Bacterial manganese and iron reduction in aquatic sediments. Adv Microb Ecol 16:41-84

Thamdrup B, Finster K, Hansen JW, Bak F (1993) Bacterial disproportionation of elemental sulfur coupled to chemical-reduction of iron or manganese. Appl Environ Microbiol 59:101-108

Thamdrup B, Fossing H, Jørgensen BB (1994) Manganese, iron, and sulfur cycling in a coastal marine sediment, Aarhus Bay, Denmark. Geochim Cosmochim Acta 58:5115-5129. doi:10.1016/0016-7037(94)90298-4

Thamdrup B, Hansen JW, Jørgensen BB (1998) Temperature dependence of aerobic respiration in a coastal sediment. FEMS Microbiol Ecol 25:189-200. doi:10.1016/S0168-6496(97) 00095-0

Theune A (2005) Biogeochemische und isotopengeochemische Untersuchungen in einem tidalen Mischwatt der südlichen Nordsee. University of Erlangen, Diploma thesis

Thode-Andersen S, Jørgensen BB (1989) Sulfate reduction and the formation of ${ }^{35} \mathrm{~S}$-labeled $\mathrm{FeS}, \mathrm{FeS}_{2}$ and $\mathrm{S}^{\circ}$ in coastal marine sediments. Limnol Oceanogr 34:793-806

Tillmann U, Hesse KJ, Colijn F (2000) Planktonic primary production in the German Wadden Sea. J Plankton Res 22:1253-1276. doi:10.1093/plankt/22.7.1253

Trudinger PA (1992) Bacterial sulfate reduction: current status and possible origin. In: Schidlowski M, Golubic S, Kimberley MM, McKirdy DM, Trudinger PA (eds) Early organic evolution. Berlin, Springer, pp 367-377

Volkman JK, Rohjan D, Rullkötter J, Scholz-Böttcher BM, Liebezeit G (2000) Sources and diagenesis of organic matter in tidal flat sediments from the German Wadden Sea. Cont Shelf Res 20:1139-1158. doi:10.1016/S0278-4343(00)00016-9

Vosjan JH (1974) Sulfate in water and sediment of the Dutch Wadden Sea. Neth J Sea Res 8:208-213. doi:10.1016/0077-7579(74)90017-9

Vosjan JH (1987) A sketchy outline of the fate of organic matter in the Dutch Wadden Sea. Hydrobiol Bull 21:127-132. doi:10.1007/ BF02255437

Walsh JJ (1991) Importance of continental margins in the marine biogeochemical cycling of carbon and nitrogen. Nature 350:5355. doi: $10.1038 / 350053 \mathrm{a} 0$

Werner U, Polerecky L, Walpersdorf E, Franke U, Billerbeck M, Böttcher ME, Ferdelman T, Beer D (2003) Organic matter degradation processes in permeable sediments - methodological approaches. Ber Forschungszentrum Terramare 12:122-125

Werner U, Billerbeck M, Polerecky L, Franke U, Hüttel M, van Beusekom JEE, de Beer D (2006) Spatial and temporal patterns of mineralization rates and oxygen distribution in a permeable intertidal sand flat (Sylt, Germany). Limnol Oceanogr 51:2549-2563

Westrich JT, Berner RA (1988) The effect of temperature on rates of sulfate reduction in marine sediments. Geomicrobiol J 6:99-117. doi:10.1080/01490458809377828

Wilms R, Sass H, Köpke B, Köster J, Cypionka H, Engelen B (2006) Specific bacterial, archaeal, and eukaryotic communities in tidal-flat sediments along a vertical profile of several meters. Appl Environ Microbiol 72:2756-2764. doi:10.1128/AEM.72.4.2756-2764.2006

Wilms R, Sass H, Köpke B, Cypionka H, Engelen B (2007) Methane and sulfate profiles within the subsurface of a tidal flat are reflected by the distribution of sulfate-reducing bacteria and methanogenic archaea. FEMS Microbiol Ecol 59:611-621. doi:10.1111/j.1574-6941.2006.00225.x

Wollast R (1991) The coastal organic carbon cycle: fluxes, sources, and sinks. In: Mantoura MRFC, Martin JM, Wollast R (eds) Ocean margin processes in global change. Wiley, London, pp 365-382 